\title{
ОПИТУВАЛЬНИК ОСОБИСТІСНОЇ ЗДІЙСНЕННОСТІ: ТЕОРЕТИЧНІ ПІДТАВИ ДЛЯ РОЗРОБКИ ТА РЕЗУЛЬТАТИ АПРОБАЦІї
}

УДК: 159.923 .2

\section{Штепа Олена Станіславівна}

Кандидат психологічних наук, дочент, дочент кафедри психології, Львівський національний університет імені Івана Франка, м. Львів (Украӥна)

\begin{abstract}
Анотація. Охарактеризовано прикладні проблеми особистісного самоздійснення та обтрунтовано доцільність терміну «особистісна здійсненність». Показано, щуо крайніми точкам контуальності особистісного самоздійснення як процесу є «справжність - фантастичність». Обтрунтовано, щэо психологічні ресурси можуть бути одиницями дискретності особистісного самоздійснення. Особистісну здійсненність охарактеризовано як ресурсний стан, щзо уможливлює втілення людиною розв'язання власної життєвої задачі у вчинку. Наведено результати розробки й апробації авторського опитувальника особистісної здійсненності. Емпірично виведено, щзо головними характеристиками особистісної здійсненності $\epsilon$ чітко поставлені иілі, прийняття «Іншого», продуктивне усамітнення, відповідальність за власний вибір. Доведено доцільність виокремлення зовнішньої $i$ внутрімньої форми особистісної здійсненності, які відповідно можна інтерпретувати, як здатність людини бути зрозумілою для інших і себе.
\end{abstract}

Ключові слова: особистість, особистісне самоздійснення, особистісна здійсненність, особистісний опитувальник.

Постановка проблеми. Особистісне самоздійснення нині відомо відносно професійного самоздійснення людини. На наш погляд, не доцільно протиставляти особистісне і професійне самоздійснення, водночас важливо схарактеризувати їх гармонійне співвідношення у контексті життєвого шляху особис- тості. Водночас реалізація такої ідеї ускладнюється відсутністю емпіричних методів визначення особистісного самоздійснення. Звісно, теоретичний аналіз характеристик особистісного самоздійснення є доцільним. Водночас до тепер на теоретичному рівні особистісне самоздійснення слушно визначують як 
процес, який складно надається дискретному опису. Окрім цього, концепціалізація характеристик особистісного самоздійснення може бути зумовлена персональною життєвою філософією науковця, виявлена у формі особистого наративу саморозвитку, що є цінним і цікавим, водночас складно верифікованим, тому важливим є емпірична верифікація теоретичних поглядів. Емпіричні дані щодо особистісного самоздійснення могли б дати змогу уточнити пропорційність і сумірність особистісного і професійного самоздійснення людини, а також вичерпніше охарактеризувати потенційність людини, іiі спрямованість, змістовність саморозвитку, виразність її особистості, виокремити нові, сучасні аспекти аналізу осмисленості життя.

Аналіз останніх досліджень і публікацій. У класичній психології особистості самоздійснення вважали результатом акмеологічного розвитку людини, підсумком формування іiі індивідуальності у концепціях особистості класичної раціональності. Тому самоздійснення трактували як «переведення можливостей людини у дійсність» (А. Джевірс за О. Кокун [2, с. 2]), як «шлях такого проходження життя, у результаті якого людина «приходить до себе» і реалізує себе» (М. Мамардашвілі за О. Кокун [2, с. 2]). У наукових розвідках ведеться щодо життєвого, професійного, особистісного самоздійснення. Життєве самоздійснення людини означено, як результат відкритості психологічної системи до світу, у майбу- тнє, який визначає інтенціональність руху системи, здатності особи до взаємодії зі світом 3 метою реалізування життєвих виборів [6]. Професійне самоздійснення характеризують як «розкриття особистісного потенціалу фахівця $<\ldots>$ » $[2$, с. 4$]$. Означення самоздійснення у концептах (перед)визначеності, на наш погляд, зумовило ототожнення цього поняття із самореалізацією і його тьмяність серед психологічних характеристик особистості.

Концепціалізація суті особистості у некласичній раціональності дала змогу науковцям визначити саморозвиток та саморегуляцію як фундаментальні якості особистості [7, c. 11], та також охарактеризувати самоздійснення процесуально і вказати, що воно «виступає як творчість і форма екзистенційного розкриття людини» [10, с. 23$]$.

Доцільно уточнити, що в екзистенціальному ракурсі особистість охарактеризовано, як «актуалізацію життєвого процесу в незалежній індивідуальності, яка є соціально інтегрованою та характеризується духовним напруженням» [8, с. 34], причому способом буття людини у світі допущено саморозуміння [1, c. 211]. Власне через саморозуміння, що формується на основі самопізнання, вибудовується, на погляд I. Корнаракіса [4, с.29,42,44], істинний або ілюзорним, фантастичний образ людини самої себе. В екзистенціальні психології особистості сутність людини визначують у співвідношенні із буттям у двох напрямах $[15$, с.186]: персоналістичний, у якому ствер- 
джується, що особа приходить до власної сутності через існування; онтологічний, який обгрунтовує, що особа розкриває власну сутність в існуванні.

Особистісне самоздійснення у концепціях некласичної раціональності визначено як «свідомий саморозвиток людини, в процесі якого розкриваються її потенційні можливості у різних життєвих сферах, результатом чого $€$ постійне досягнення особистісно та соціально значущих ефектів, формування власного «простору життя» [2, с. 3] або, як «самоконструювання, що здійснюється в умовах діалогу людини зі світом та презентується у «послідовності конфігурування та переконфігурування особистістю меж інтерпретації свого життя» $[16$, с. $5,8,40]$. О. Кокуном виокремлено внутрішню (значущішу) і зовнішню форми самоздійснення [2, с. 3], розроблено опитувальник професійного самоздійснення $[2$, c. 3], теоретично виведено ознаки особистісного самоздійснення - наявність у людини власного проекту життя і вираженої потреби у саморозвитку, розкриття особою власного потенціалу, безупинність у постановці нових цілей і задоволення від їх досягнення, обов'язкове визнання досягнень з боку інших [3, с. 3], а також вказано, що самоздійснення відрізняє від самореалізації безупинність і незалежність від зовнішніх умов [2, с. 3]. Зокрема механізмом особистісного саморозвитку вказано самозміни, спрямовані на усунення суперечностей між внутрішньою суб'єктивною реальніс- тю, життєвими задачами та ресурсами, які є у розпорядженні в людини [9, с. 367].

Отож, особистісне самоздійснення доцільно охарактеризувати, як один з модусів життєвого самоздійснення, який у співвідношенні з професійним самоздійсненням зумовлює унікальність життєвого шляху людини. Значущим $є$ те, що самоздійснення розкривається саме у екзистенціальному ракурсі. Відтак, особистісне у самоздійсненні характеризується не показниками соціальної затребуваності, а через відповідність до істини, справжність. Вважаємо, що крайніми точками континууму особистісного самоздійснення можна визначити «справжність» та «фантастичність». На перший погляд, персоналістичний напрям $\epsilon$ відповіднішим до аналізу особистісного у самоздійсненні людини. Водночас інтерпретації, через які людина може прийти до саморозуміння, часто насичені суспільними, соціальними схемами тлумачень $[11$, с. 12$]$, що не обов'язково приведуть іiі до розуміння власної справжньої сутності. Погляди науковців онтологічного напряму збігаються із характеристикою самоздійснення як процесу, незалежного від зовнішніх умов. Відтак, тлумачення саморозуміння людиною власної справжності $\epsilon$ аргументованішим в онтологічному напрямі.

\section{Основний матеріал та результати до-} слідження. Проблема емпіричного об'єктивування характеристик особистісного самоздійснення може бути розв'язана, якщо обгрунтувати одиниці дискретності особистісного самоз- 
дійснення, які водночас мають бути ідентичними із змістом його процесу. Реалізація такого обгрунтування була означена нами за мету дослідження. Гіпотези дослідження: 1) теоретичне припущення, що психологічні ресурси $\epsilon$ одиницями дискретності особистісного самоздійснення, 2) емпіричне припущення, що фіксована структура психологічних ресурсів характеризує завершеність особистісного самоздійснення відносно певної життєвої задачі. Завдання дослідження: 1) теоретичні: умотивувати, що психологічні ресурси є одиницями дискретності особистісного самоздійснення, а також аргументувати доцільність поняття «особистісна здійсненність» як екзистенціальної інваріанти завершеності особистісного самоздійснення відносно певної життєвої задачі, 2) емпіричні: обгрунтувати, що психологічні ресурси є одночасно процесуальною і дискретною властивістю особистісного самоздійснення; вивести консервативну структуру психологічних ресурсів; розробити і апробувати психологічний опитувальник для визначення характеристик особистісної здійсненності. Методи дослідження: теоретичні - аналіз і систематизація, емпіричні - психологічне опитування, а також математико-статистичні методи аналізу даних (кластерний, кореляційний, багатофакторний, регресійний аналіз).

Особистісне самоздійснення ми тлумачимо, як ресурсно зумовлений процес рефлексивного розгортування людиною власної сутності в ході самозміни через інтерпретування контроверзів персоналізації та персоніфікації [13, с. 215]. Функціональним виявом особистісного самоздійснення ми визначили психологічну ресурсність, яку визначуємо, як уміння людини актуалізовувати власні ресурси, тобто свідомо оперувати ними, а саме: знати їх, уміти вміщувати та оновлювати [12, с. 384]. Ресурси ми характеризуємо як опори інтерпретації людиною осягнення, отриманого нею у ії екзистенціальному досвіді, необхідні для переведення потенцій власної сутності в особистісну форму та реалізації можливості здійснитися відносно істини [12, с. 384]. Оскільки способом буття людини у світі вказано саморозуміння [1, с. 211], а його механізмом є інтерпретація [11, с. 24], то ймовірним є те, що психологічні ресурси як опори інтерпретації можуть бути одиницями уможливлення особистісної здійсненності.

Вважаємо, що для уможливлення дискретного опису особистісного самоздійснення емпіричним способом доцільно за аналогію 3 поняттям А. Ленгле «екзистенціальна здійсненність» (за С. Крівцова [5]) прийняти поняття «особистісної здійсненності». «Екзистенціальна здійсненність» виявляє здатність людини знаходитись у діалогічному обміні зі світом і тим самим прийти до здійснення власної сутності (за С. Крівцова [5]). А. Ленгле розроблено опитувальник екзистенціальної здійсненності (за С. Крівцова [5]), а підхід науковця до сутності особистості $є$ персоналістичним. На наш погляд, емпірично екзистен- 
ціальна здійсненність і особистісна здійсненність можуть збігатися на загальному рівні, але $є$ несхожими у характеристиках, оскільки за персоналістичного підходу процеси здійсненності розглядаються, як кроки до «нової особистості», а за онтологічного - як миттєве перетворення особистості.

На основі даних щодо співвідношення понять здійснення і здійсненності, а також умовиводу про психологічну ресурсність як здатність людини оперувати власними ресурсами, що $\epsilon$ функціональним виявом процесу особистого самоздійснення, та про психологічні ресурси як одиниці уможливлення особистісної здійсненності, ми зробили такі висновки щодо особистісної здійсненності: 1) функціонально особистісна здійсненність є дискретним показником завершеності процесу особистісного самоздійснення відносно певної життєвої задачі, 2) змістовно особистісна здійсненність виявляється як ресурсний стан, що уможливлює втілення людиною розв'язання власної життєвої задачі у вчинку. Обгрунтування теоретичних засад дослідження дало змогу перейти до розв'язання емпіричних завдань.

В емпіричному дослідженні консервативної структури психологічних ресурсів, а також у розробці та апробації психологічного опитувальника особистісної здійсненності (O3) взяли участь усього 542 осіб віком 18-77 років $(\mathrm{M}=36,6 ; \mathrm{SD}=14,27 ; 27 \%$ - чоловіки, $73 \%$ - жінки). Серед респондентів -, студенти університетів 2-6 курсу денної форми навчання гуманітарних і природничих спеціальностей, викладачі університетів і коледжів, приватні підприємці, менеджери, правники, психологи, лікарі, домогосподарки, пенсіонери.

3 метою реалізації ідеї щодо можливості визначення особистісної здійсненності способом аналізу консервативної структури психологічних ресурсів було здійснено конфірматорний багатофакторний аналіз запитань за авторським опитувальником психологічної ресурсності [12, с.384], який виявив 22факторну структуру компонентів особистісної здійсненності, що загалом пояснює 57,3\% дисперсії (факторна вага >0,7). До подальшого математико-статистичного опрацювання за допомогою конфірматорного багатофакторного аналізу було залучено питання з факторною вагою >0,56, з метою забезпечення змістової насиченості запланованого результату. Відтак наступна емпірична модель містила 17 факторів і кумулятивно пояснювала 74,2\%. Через три ітерації було визначено чотирифакторну емпіричну модель особистісної здійсненності, що загалом пояснювала 82,91\% дисперсії, зокрема, фактор 1 пояснював 29,55\% дисперсії, фактор 2 - 20,85\%, фактор 3 - 17,82\%, фактор 4 - 14,69\%. Результати факторизації питань опитувальника О3 вміщено у табл.1.

Запитання, що увійшли до фактору 1 ми контекстуально узагальнили під назвою «чітко поставлені цілі», фактору 2 «прийняття Іншого», фактору 3 - 
«продуктивне усамітнення», фактору 2 - ми особистісної здійсненності.

«відповідальність за власний вибір». Виокрем-

Для встановлення сумірності виокрем-

лені фактори ми припустили характеристика-

лених характеристик було засновано кластер-

\section{Факторизація пунктів опитувальника О3}

Таблиия 1.

\begin{tabular}{|l|c|c|c|c|}
\hline \multicolumn{1}{|c|}{ Пуннкти опитувальника } & Фактор 1 & Фактор 2 & Фактор 3 & Фактор 4 \\
\hline 2. Наполегливість - це мій шлях до успіху & 0,73 & & & \\
\hline 21. Не вважаю себе цілеспрямованою людиною & $-0,82$ & $-0,73$ & & $-0,68$ \\
\hline $\begin{array}{l}\text { 37. Я вмію надихати інших на творчі рішення або добрі } \\
\text { вчинки }\end{array}$ & 0,77 & & & \\
\hline 39. Мені подобається розмірковувати, філософствувати & 0,63 & 0,70 & 0,75 & \\
\hline 40. Я відчуваю життя більш повно, коли прагну цілі & 0,81 & & & 0,73 \\
\hline $\begin{array}{l}\text { 58. Я відчуваю життя більш повно, коли здатний люби- } \\
\text { ти }\end{array}$ & 0,65 & 0,69 & & \\
\hline 61. Я знаю, як себе організувати, щоб досягти мети & 0,69 & 0,64 & & \\
\hline $\begin{array}{l}\text { 65. Близьким та колегам по роботі важлива моя мораль- } \\
\text { на підтримка }\end{array}$ & 0,58 & & & \\
\hline $\begin{array}{l}\text { 15. Я намагаюсь уникати людей, які можуть у мене } \\
\text { щось попросити }\end{array}$ & & $-0,59$ & & $-0,63$ \\
\hline 30. Мені є кого любити & & 0,76 & & \\
\hline 31. Мені цікаві люди, які мислять неординарно & & 0,70 & & \\
\hline $\begin{array}{l}\text { 38. Я вмію пропонувати свою допомогу, не принижую- } \\
\text { чи людини }\end{array}$ & & 0,72 & & \\
\hline 3. Загалом, я впевнена у собі людина & & 0,68 & \\
\hline $\begin{array}{l}\text { 14. Для мене важливо, щоб мої зусилля не були марни- } \\
\text { ми }\end{array}$ & & & 0,75 & \\
\hline $\begin{array}{l}\text { 13. Я волію тримати при собі свої речі, думки та пере- } \\
\text { живання }\end{array}$ & & & $-0,72$ & \\
\hline 48. Я не бачу перспектив саморозвитку & & & $-0,72$ & \\
\hline $\begin{array}{l}\text { 60. Час від часу мені необхідно побути наодинці, щоб } \\
\text { поміркувати над життям }\end{array}$ & & & 0,82 & \\
\hline 66. Я не здатний робити щось, щоб почуватись у безпеці & & & $-0,67$ & $-0,67$ \\
\hline $\begin{array}{l}\text { 64. Я не знаю меж власних творчих та професійних мо- } \\
\text { жливостий }\end{array}$ & & & $-0,78$ & $-0,78$ \\
\hline 8. Мені не подобається відповідати за інших & & & $-0,62$ \\
\hline $\begin{array}{l}\text { 9. Коли необхідно приймати рішення, я не впевнений, } \\
\text { що оберу вірний варіант }\end{array}$ & & & $-0,70$ \\
\hline $\begin{array}{l}\text { 22. Якщо завдання відповідальне, намагаюсь його уник- } \\
\text { нути }\end{array}$ & & & $-0,65$ \\
\hline
\end{tabular}

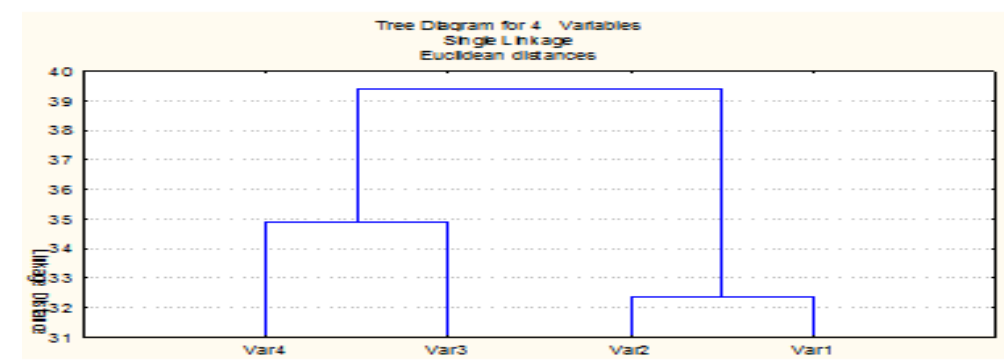

Умовні позначення: Var 1 - фактор 1 опитувальника О3, Var 2 - фактор 2 опитувальника О3, Var 3 - фактор 3 опитувальника O3, Var 4 - фактор 4 опитувальника O3.

Рис.1. Дерево кластеризації показників особистісної здійсненності 
ний аналіз (Tree Diagram/E) (Рис.1).

На основі змістового аналізу пунктів опитувальника О3, що увійшли до чотирьох факторів, та результатів кластерного аналізу ми вирішили за доцільне контекстуально об'єднати пункти фактору 1 та фактору 2, а також i 4. Також алгебраїчно було обчислено загальну суму балів за усіма пунктами О3. На наш погляд, такі дії мали увиразнити структуру особистісної здійсненності так, щоб уможливити характеристику іï внутрішньої і зовнішньої форми. Результат вчинених маніпуляцій

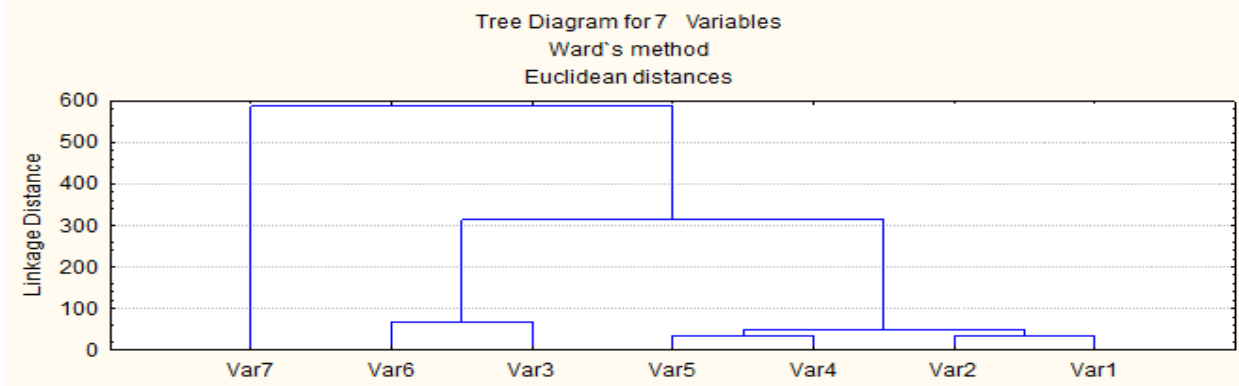

Умовні позначення: Var 1 - фактор 1 опитувальника О3, Var 2 - фактор 2 опитувальника О3, Var 3 - зовнішня форма O3, Var 4- фактор 3 опитувальника O3, Var 5 - фактор 4 опитувальника О3, Var 6- внутрішня форма О3, Var 7 - загальний рівень О3.

Рис.2. Дерево кластеризації головних характеристик особистісної здійсненності

вивести алгебраїчну суму балів за пунктами, ми перевірили методами кластерного (Рис.2). що увійшли до цих факторів. Аналогічну проПозитивні результати кластерного анацедуру було здійснено щодо змісту факторів 3 лізу головних характеристик особистісної

Результати регресійного аналізу щодо чинників загального рівня психологічної

Таблиия 2. ресурсності

\begin{tabular}{|c|c|c|c|c|c|c|}
\hline & Beta & $\begin{array}{c}\text { Std.Err. - of } \\
\text { Beta }\end{array}$ & B & $\begin{array}{c}\text { Std.Err. - of } \\
\text { B }\end{array}$ & $\mathrm{t}(492)$ & p-level \\
\hline Уміння вмішувати власні ресурси $^{*}$ & 0,072 & 0,029 & 0,047 & 0,03 & 2,45 & 0,014749 \\
\hline Любов & 0,114 & 0,022 & 0,089 & 0,017 & 5,13 & 0,000000 \\
\hline Самореалізація у професії & 0,109 & 0,020 & 0,077 & 0,014 & 5,34 & 0,000000 \\
\hline Допомога іншим & 0,121 & 0,019 & 0,088 & 0,014 & 6,05 & 0,000000 \\
\hline Робота над собою & 0,133 & 0,0180 & 0,103 & 0,014 & 7,37 & 0,000000 \\
\hline Знання власних ресурсів & 0,157 & 0,028 & 0,097 & 0,018 & 5,517 & 0,000000 \\
\hline Успіх & 0,082 & 0,017 & 0,068 & 0,014 & 4,847 & 0,000002 \\
\hline Допомога іншим & 0,109 & 0,018 & 0,092 & 0,015 & 5,95 & 0,000000 \\
\hline Прагнення мудрості & 0,089 & 0,017 & 0,072 & 0,014 & 5,15 & 0,000000 \\
\hline Впевненість у собі & 0,111 & 0,018 & 0,063 & 0,011 & 6,02 & 0,000000 \\
\hline Творчість & 0,102 & 0,021 & 0,073 & 0,015 & 4,81 & 0,000002 \\
\hline Уміння оновлювати власні ресурси & 0,139 & 0,028 & 0,097 & 0,111 & 4,890 & 0,000001 \\
\hline Віра у добро & 0,080 & 0,019 & 0,067 & 0,016 & 4,28 & 0,000022 \\
\hline Відповідальність & 0,055 & 0,021 & 0,040 & 0,015 & 2,69 & 0,007445 \\
\hline
\end{tabular}

$*(p<0,05)$ 
здійсненності, який виявив чітку змістову структурованість різних компонентів О3, дали змогу здійснити перевірку припущення щодо психологічних ресурсів як одиниць уможливлення здійсненності.

Для емпіричної перевірки того, що психологічні ресурси є одночасно процесуальною і дискретною властивістю особистісного самоздійснення, було здійснено регресійний аналіз.

За результатами регресійного аналізу $(\mathrm{p}<0,01)$ виявлено, що чинниками загального рівня психологічної ресурсності $є$ усі психологічні ресурси за винятком уміння вміщувати власні ресурси (ця компонента ресурсності $€$ чинником загального рівня психологічної ресурсності за $(\mathrm{p}<0,05)$ (Табл.2).

Такі результати були очікувані, адже опитувальник психологічної ресурсності пройшов перевірку надійності й валідності. За результатами регресійного аналізу $(\mathrm{p}<0,01)$ виявлено психологічні ресурси, що є головни-

\section{Результати регресійного аналізу щодо чинників загального рівня особистісної здійсненності}

\begin{tabular}{|l|c|c|c|c|c|c|}
\hline & Beta & $\begin{array}{c}\text { Std.Err. - } \\
\text { of Beta }\end{array}$ & B & $\begin{array}{c}\text { Std.Err. - } \\
\text { of B }\end{array}$ & $\mathrm{t}(496)$ & $\mathrm{p}-\mathrm{level}$ \\
\hline Уміння вміщувати власні ресурси & 0,279 & 0,068 & 0,088 & 0,022 & 4,08 & 0,000053 \\
\hline Впевненість у собі & 0,268 & 0,043 & 0,074 & 0,012 & 6,28 & 0,000000 \\
\hline Уміння оновлювати власні ресурси & 0,322 & 0,067 & 0,109 & 0,023 & 4,83 & 0,000002 \\
\hline Знання власних ресурсів & $-0,221$ & 0,067 & $-0,066$ & 0,019 & $-3,30$ & 0,001033 \\
\hline Прагнення мудрості* & 0,092 & 0,039 & 0,036 & 0,015 & 2,33 & 0,020004 \\
\hline Любов* & $-0,144$ & 0,042 & $-0,055$ & 0,016 & $-3,44$ & 0,000629 \\
\hline Доброта до людей* & 0,085 & 0,038 & 0,035 & 0,016 & 2,23 & 0,026395 \\
\hline Творчість & 0,108 & 0,049 & 0,038 & 0,017 & 2,22 & 0,026924 \\
\hline Робота над собою* & 0,074 & 0,042 & 0,028 & 0,016 & 1,75 & 0,080013 \\
\hline
\end{tabular}

$$
*(p<0,05)
$$

ми чинниками загального рівня особистісної здійсненності (Табл.3), а саме:

Порівняння результатів регресійного аналізу виявило, що, в цілому, 62\% психологічних ресурсів $є$ компонентами особистісної здійсненності. Основними психологічними ресурсами, що характеризують, як плин, так i структуру особистого самоздійснення є знання власних ресурсів та уміння їх вміщувати і оновлювати (показники власне ресурсності як уміння оперувати власними ресурсами), а також впевненість у собі, доброта до людей, прагнення мудрості, творчість, робота над собою.

Для з'ясування змістової структурованості психологічних ресурсів і характеристик особистісної здійсненності було використано Шкалу екзистенції (Existenzskala) А. Ленгле та К. Орглера (адаптація С. Крівцової) та застосовано конфірматорний багатофакторний аналіз, який, пояснюючи загалом $71 \%$ дисперсії (факторна вага > 0,7), показав, що фактор 1

Таблиия 3. 

знання власних ресурсів та уміння їх оновлювати і вміщувати; фактор 2 (10,2\%) - психологічні ресурси допомоги іншим, доброта до людей, віри у добро; фактор 3 (6,6\%) - показники O3: фактор 1, фактор 2, зовнішня форма О3.

Результати багатофакторного i регресійного аналізу звернули увагу на те, що саме показники уміння оперувати власними психологічними ресурсами $є$ предикторами консервативної структури психологічних ресурсів, що може бути проінтерпретовані, як стан здійсненності. Наявні результати надали підстав для подальшого математико-статистичного обгрунтування показників особистісної здійсненності (О3).

За результатами експлораторного факторного аналізу ( $\mathrm{N}=542$; факторна вага $>0,7)$ встановлено двофакторну стійку структуру особистісної здійсненності, що загалом пояснює 87,7\% дисперсії (Табл.4).

Конфірматорний багатофакторний аналіз (Principal components, Varimax normalized) виявив чіткий поділ характеристик О3 на ком-

\section{Факторна структура O3}

\section{Таблиия 4.}

\begin{tabular}{|c|l|l|l|l|}
\hline & Eigenvalue & $\begin{array}{c}\text { \% Total - } \\
\text { variance }\end{array}$ & $\begin{array}{c}\text { Cumulative } \\
\text { - Eigenvalue }\end{array}$ & $\begin{array}{c}\text { Cumulative } \\
-\%\end{array}$ \\
\hline 1 & 4,877133 & 69,67333 & 4,877133 & 69,67333 \\
\hline 2 & 1,259639 & 17,99484 & 6,136772 & 87,66818 \\
\hline
\end{tabular}

Факторні навантаження характеристик О3 (факторна вага $>0,7$ )

\begin{tabular}{|c|c|c|}
\hline & Factor - 1 & Factor - 2 \\
\hline Чітко поставлені цілі & $\mathbf{0 , 9 1 3 5 6 2}$ & 0,247579 \\
\hline Прийняття Іншого & $\mathbf{0 , 8 9 9 8 0 5}$ & 0,227829 \\
\hline $\begin{array}{l}\text { Зовнішня форма особисті- } \\
\text { сної здійсненності }\end{array}$ & 0,965550 & 0,254447 \\
\hline Продуктивне усамітнення & 0,179470 & $\mathbf{0 , 8 2 9 8 1 8}$ \\
\hline $\begin{array}{l}\text { Відповідальність за власні } \\
\text { вчинки }\end{array}$ & 0,280517 & 0,777765 \\
\hline $\begin{array}{l}\text { Внутрішня форма особис- } \\
\text { тісної здійсненності }\end{array}$ & 0,273796 & 0,961309 \\
\hline $\begin{array}{l}\text { Загальний рівень особисті- } \\
\text { сної здійсненності }\end{array}$ & 0,765483 & 0,626766 \\
\hline
\end{tabular}

Примітки: До фактора 1 увійшли характеристики і загальний показник зовнішньої форми особистісної здійсненності, а також загальний рівень О3; до фактора 2 - характеристики і загальний показник внутрішньої форми особистісної здійсненності.

поненти зовнішньої і внутрішньої форми О3 (Табл.5).

Для перевірки змістової достовірності шуканого показника загального рівня особистісної здійсненності через наявність його збігу 3 загальним рівнем екзистенціальної здійсненності було застосовано класифікаційний аналіз (метод Predictor Variable Importance Rankings), результати якого вміщено у Табл. 6.

Ранги показників О3 як предикторів загального рівня особистісної та екзистенціальної здійсненності виявились ідентичними. Вважаємо, цей факт свідчить про достовірність характеристик О3 саме показників здійсненності, тобто проміжного результату, завершеності.

На подальше характеристики О3 розглядались так: по-перше, базовим факторам 
Результати класифікаційного аналізу предикторів

Таблиия 6.

\section{загального рівня особистісної та екзистенціальної здійсненності}

\begin{tabular}{|l|c|c|}
\hline \multirow{2}{*}{\multicolumn{1}{|c|}{ Характеристики О3 }} & \multicolumn{2}{|c|}{ Ранг предиктора* } \\
\cline { 2 - 3 } & $\begin{array}{c}\text { для показника } \\
\text { «загальний рівень екзистенціальної здійс- } \\
\text { ненності» }\end{array}$ & $\begin{array}{c}\text { для показника «загальний рівень особисті- } \\
\text { сної здійсненності» }\end{array}$ \\
\hline Чітко поставлені цілі & 85 & 85 \\
\hline Прийняття Іншого & 76 & 76 \\
\hline $\begin{array}{l}\text { Зовнішня форма особистісної здійсненно- } \\
\text { сті }\end{array}$ & 100 & 59 \\
\hline Продуктивне усамітнення & 59 & 40 \\
\hline Відповідальність за власні вчинки & 40 & 79 \\
\hline $\begin{array}{l}\text { Внутрішня форма особистісної здійснен- } \\
\text { ності }\end{array}$ & 79 & 700 \\
\hline
\end{tabular}

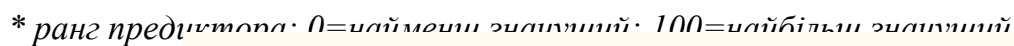

Tree Diagram for 14 Variables

Ward's method

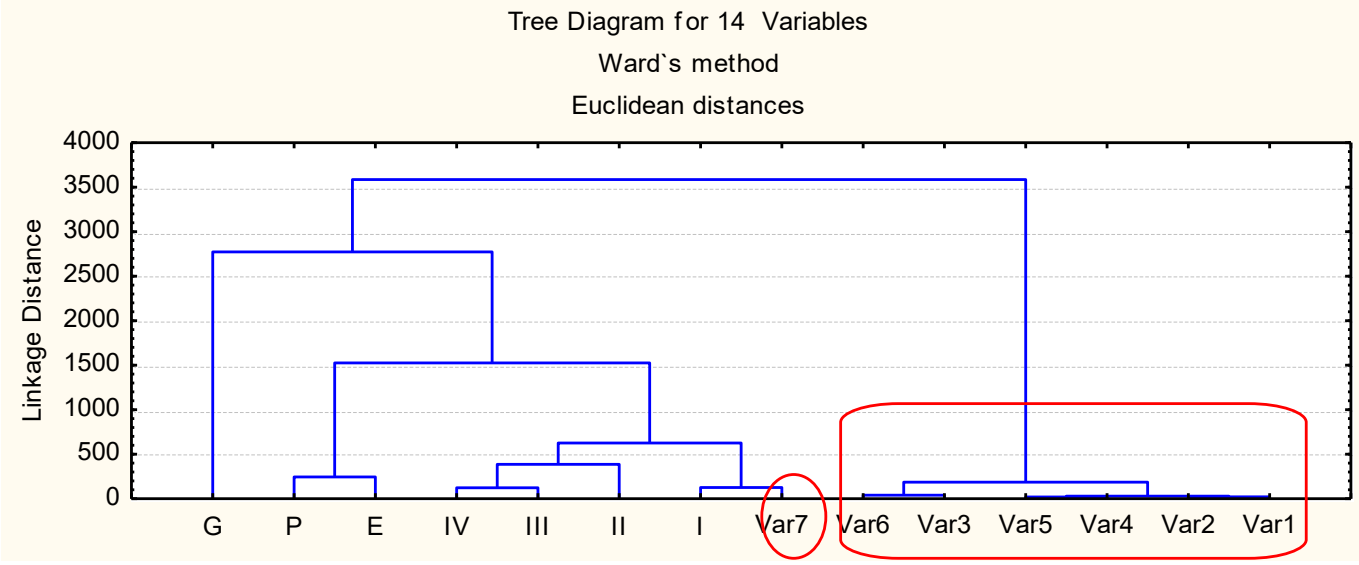

Умовні позначення: Var 1 - чітко поставлені иілі, Var 2 - прийняття Іншого, Var 3 - зовнішня форма особистісної здійсненності, Var 4 - продуктивне усамітнення, Var 5 - відповідальність за власний вибір, Var 6-внутрішня форма особистісної здійсненності, Var 7 - загальний рівень особистісної здійсненності; I - самодистаниіювання, II - самотрансиендениії, III - свобода, IV - відповідальність, E- екзистениіальність, P - персональність, $G$ - загальний показник екзистениіальної здійсненності

\section{Рис.3. Дерево кластеризації головних характеристик особистісної здій- сненності та показників екзистенціальної здійсненності}

було дано назви (фактор 1 - «чітко поставлені цілі», фактор 2 - «прийняття Іншого», фактор 3 - «продуктивне усамітнення», фактор 4 «відповідальність за власний вибір»), подруге, вказано такі характеристики особистісної здійсненності, що стали показниками опитувальника О3: 1) чітко поставлені цілі, 2) прийняття Іншого, 3) зовнішня форма особис- тісної здійсненності, 4) продуктивне усамітнення, 5) відповідальність за власний вибір, 6) внутрішня форма особистісної здійсненності, 7) загальний рівень особистісної здійсненносri.

Кластерний аналіз показників О3 і екзистенціальної здійсненності показав, що загальний рівень О3 змістовно $є$ наближеним до 
такого показника екзистенційної здійсненності, як самодистанціювання (Рис.3).

Слід звернути увагу на змістову відокремленість показників особистісної і екзистенціальної здійсненності. Змістову наближеність самодистанціювання і загального рівня особистісної здійсненності ми проінтерпретували, як те, що індикатором особистісної здійсненності проміжної завершеності особистісного самоздійснення є здатність людини до створення вільного внутрішнього простору для усвідомлення і незалежного аналізу себе у ситуації.

У Табл. 7 показано результати кореляційного аналізу показників О3 та екзистенційної здійсненності.

За даними Табл. 8 можна стверджувати, що особистісна і екзистенціальна здійсненність мають збіг через персональність, тобто відкритість людини до світу і для себе. Ми вважаємо, що такий вияв відкритості можна інтерпретувати 3 погляду особистісної здійсненності, як здатність людини бути зрозумілою для себе та інших. Водночас відповідність як процес екзистенціальної здійсненності, а також екзистенціальність як здатність рішуче включатися до життя, визначною мірою пов'язані саме $з$ зовнішньою формою особистісної здійсненності. Коливання абсолютної величини коефіцієнтів кореляції є у діапазоні 0,25 0,55 ( $\mathrm{p}<0,001$ ), що свідчить про неідентичність показників методик.

Конструктну валідність опитувальника О3 було визначено за допомогою багатофакторного, кореляційного, кластерного аналізу (результати багатофакторного і кластерного аналізу з міркувань доцільності було розміщено вище).

Табличя 7.

\section{Кореляційні зв'язки О3 і екзистенціальної здійсненності (N=190)}

\begin{tabular}{|c|c|c|c|c|c|c|c|}
\hline \multirow[b]{2}{*}{ Показники О3 } & \multicolumn{7}{|c|}{ Показники екзистенціальної здійсненності } \\
\hline & \begin{tabular}{|c|} 
Самодис- \\
танціюван \\
ня (I)
\end{tabular} & $\begin{array}{c}\text { Самотран- } \\
\text { сценденці } \\
\text { я (II) }\end{array}$ & $\begin{array}{c}\text { Свобода } \\
\text { (III) }\end{array}$ & \begin{tabular}{|} 
Відповіда- \\
льність \\
(IV)
\end{tabular} & $\begin{array}{l}\text { Екзистен- } \\
\text { ціальність }\end{array}$ & $\begin{array}{c}\text { Персона- } \\
\text { льність }\end{array}$ & $\begin{array}{c}\text { Загальний } \\
\text { рівень екзис- } \\
\text { тенціальної } \\
\text { здійсненності }\end{array}$ \\
\hline Чітко поставлені цілі & $0,34 * * *$ & $0,54 * * *$ & $0,42 * * *$ & $0,26 * * *$ & $0,29 * * *$ & $0,52 * * *$ & $0,44 * * *$ \\
\hline Прийняття Іншого & $0,25 * * *$ & $0,60 * * *$ & $0,31 * * *$ & $0,23 * *$ & $0,28 * * *$ & $0,55 * * *$ & $0,46 * * *$ \\
\hline $\begin{array}{l}\text { Зовнішня форма особистісної } \\
\text { здійсненності }\end{array}$ & $0,32 * * *$ & $0,60 * * *$ & $0,40 * * *$ & $0,26 * * *$ & $0,31 * * *$ & $0,56 * * *$ & $0,48 * * *$ \\
\hline Продуктивне усамітнення & $0,23 * *$ & $0,29 * * *$ & $0,19 * *$ & $0,14^{*}$ & 0,11 & $0,33 * * *$ & $0,24 * *$ \\
\hline Відповідальність & 0,20 & $0,40 * * *$ & $0,26 * * *$ & 0,10 & 0,10 & $0,32 * * *$ & $0,23 * *$ \\
\hline $\begin{array}{l}\text { Внутрішня форма особистісної } \\
\text { здійсненності }\end{array}$ & $0,26 * * *$ & $0,42 * * *$ & $0,27 * * *$ & 0,14 & 0,13 & $0,39 * * *$ & $0,28 * * *$ \\
\hline $\begin{array}{l}\text { Загальний рівень особистісної } \\
\text { здійсненності }\end{array}$ & $0,31 * * *$ & $0,60 * * *$ & $0,40 * * *$ & $0,22 * *$ & $0,26 * * *$ & $0,55 * * *$ & $0,44 * * *$ \\
\hline
\end{tabular}

$* \mathrm{p}<0,05 ; * * \mathrm{p}<0,01, * * * \mathrm{p}<0,001$ 


\section{Інтеркореляційні показники характеристик $\mathrm{O3}(\mathrm{N}=542 ; \mathrm{p}<, 001)$}

\begin{tabular}{|c|c|c|c|c|c|c|c|}
\hline Шкали 03 & Var1 & Var2 & Var3 & Var4 & Var5 & Var6 & Var7 \\
\hline 1.(Var1) Чітко поставлені цілі & 1,00 & & & & & & \\
\hline 1.(Var2) Прийняття Іншого & 0,76 & 1,00 & & & & & \\
\hline 1.(Var3) Зовнішня форма особистісної здійсненності & 0,96 & 0,92 & 1,00 & & & & \\
\hline 1.(Var4) Продуктивне усамітнення & 0,38 & 0,37 & 0,40 & 1,00 & & & \\
\hline 1.(Var5) Відповідальність за власний вибір & 0,44 & 0,41 & 0,45 & 0,40 & 1,00 & & \\
\hline 1.(Var6) Внутрішня форма особистісної здійсненності & 0,49 & 0,47 & 0,51 & 0,84 & 0,83 & 1,00 & \\
\hline 1.(Var7) Загальний рівень особистісної здійсненності & 0,86 & 0,82 & 0,89 & 0,64 & 0,71 & 0,81 & 1,00 \\
\hline
\end{tabular}

У Табл. 8 вміщено дані інтеркореляції характеристик особистісної здійсненності (Табл.8).

Коливання абсолютної величини коефіцієнтів кореляції головних характеристик О3 таких, як чітко поставлені цілі, прийняття Іншого, продуктивне усамітнення, відповідальність за власний вибір, є у діапазоні 0,37 0,45 ( $<<0,001)$, що вказує на добру внутрішню узгодженість і водночас відокремленість цих показників О3. Високий рівень інтеркореляцій між головними характеристиками О3 та показниками зовнішньої і внутрішньої форми О3 пояснюється тим, що останні були виведені, як алгебраїчна сума балів за кожною з пар головних характеристик О3. Високий рівень абсолютних величин коефіцієнтів кореляції загального рівня О3 з його характеристиками, на наш погляд, характеризує саме онтологічний принцип вияву особистісної здійсненності не покроковий, а миттєвий. Такий ефект повноти, завершеності математично може виявля-

\section{Результати Tests of Normality для показників О3}

Таблиия 9.

\begin{tabular}{|l|c|c|c|c|c|c|}
\hline \multicolumn{1}{|c|}{ Показники О3 } & $\mathrm{N}$ & $\max \mathrm{D}$ & $\begin{array}{c}\text { Kolmogorov- } \\
\text { Smirnov Test - }\end{array}$ & $\begin{array}{c}\text { Lilliefors } \\
-\mathrm{p}\end{array}$ & $\begin{array}{c}\text { Shapiro- } \\
\text { Wilk’s test }\end{array}$ & $\mathrm{p}$ \\
\hline Чітко поставлені цілі & 542 & 0,190 & $\mathrm{p}<, 01$ & $\mathrm{p}<, 01$ & 0,880570 & 0,000000 \\
\hline Прийняття Іншого & 542 & 0,219 & $\mathrm{p}<, 01$ & $\mathrm{p}<, 01$ & 0,849724 & 0,000000 \\
\hline $\begin{array}{l}\text { Зовнішня форма особистісної здійснен- } \\
\text { ності }\end{array}$ & 542 & 0,154 & $\mathrm{p}<, 01$ & $\mathrm{p}<, 01$ & 0,898331 & 0,000000 \\
\hline Продуктивне усамітнення & 542 & 0,157 & $\mathrm{p}<, 01$ & $\mathrm{p}<, 01$ & 0,872189 & 0,000000 \\
\hline Відповідальність & 542 & 0,207 & $\mathrm{p}<, 01$ & $\mathrm{p}<, 01$ & 0,914880 & 0,000000 \\
\hline $\begin{array}{l}\text { Внутрішня форма особистісної здійснен- } \\
\text { ності }\end{array}$ & 542 & 0,121 & $\mathrm{p}<, 01$ & $\mathrm{p}<, 01$ & 0,965604 & 0,000000 \\
\hline $\begin{array}{l}\text { Зальний рівень особистісної здійснен- } \\
\text { ності }\end{array}$ & 542 & 0,110 & $\mathrm{p}<, 01$ & $\mathrm{p}<, 01$ & 0,956986 & 0,000000 \\
\hline
\end{tabular}




\section{Основні психометричні характеристики О3}

\begin{tabular}{|c|c|c|c|c|c|c|c|c|c|}
\hline \multirow{3}{*}{$\begin{array}{c}\text { Показники } \\
\text { особистісної здійс- } \\
\text { ненності }\end{array}$} & \multirow{3}{*}{$\begin{array}{c}\text { Кількість } \\
\text { питань у } \\
\text { шкалі }\end{array}$} & \multirow{3}{*}{$\begin{array}{c}\text { Надій- } \\
\text { ність- } \\
\text { узгодже- } \\
\text { ність } \\
\alpha \text { Кронба- } \\
\text { ха } \\
\text { (Cronbach } \\
\text { alpha: ,89) }\end{array}$} & \multicolumn{6}{|c|}{$\begin{array}{c}\text { Описова статистика } \\
(\mathrm{N}=542)\end{array}$} & \multirow{3}{*}{$\begin{array}{c}\text { Ретестова на- } \\
\text { дійність, r } \\
(\mathrm{p}<, 001) \\
\text { (часова експо- } \\
\text { зиція - } 2 \text { міс) }\end{array}$} \\
\hline & & & \multicolumn{2}{|c|}{ Уся вибірка } & \multicolumn{2}{|c|}{ Жінки } & \multicolumn{2}{|c|}{ Чоловіки } & \\
\hline & & & M & SD & M & SD & M & SD & \\
\hline $\begin{array}{l}\text { Чітко поставлені } \\
\text { цілі }\end{array}$ & 8 & 0,87 & 5,99 & 1,91 & 6,15 & 1,82 & 5,39 & 2,12 & 0,70 \\
\hline Прийняття Іншого & 8 & 0,88 & 6,63 & 1,40 & 6,73 & 1,35 & 6,26 & 1,54 & 0,65 \\
\hline $\begin{array}{l}\text { Зовнішня форма } \\
\text { особистісної здійс- } \\
\text { ненності }\end{array}$ & 16 & 0,86 & 12,63 & 3,11 & 12,88 & 2,97 & 11,64 & 3,47 & 0,75 \\
\hline $\begin{array}{l}\text { Продуктивне усамі- } \\
\text { тнення }\end{array}$ & 8 & 0,90 & 5,86 & 1,39 & 5,85 & 1,29 & 5,90 & 1,76 & 0,55 \\
\hline Відповідальність & 8 & 0,89 & 5,83 & 1,34 & 5,83 & 1,33 & 5,85 & 1,41 & 0,68 \\
\hline $\begin{array}{l}\text { Внутрішня форма } \\
\text { особистісної здійс- } \\
\text { ненності }\end{array}$ & 16 & 0,87 & 11,69 & 2,29 & 11,68 & 2,23 & 11,75 & 2,51 & 0,67 \\
\hline $\begin{array}{l}\text { Загальний рівень } \\
\text { особистісної здійс- } \\
\text { ненності }\end{array}$ & 22 & 0,87 & 24,24 & 4,73 & 24,48 & 4,64 & 23,28 & 4,97 & 0,78 \\
\hline
\end{tabular}

тись, як стремління абсолютної величини до 1,0 .

Результати кореляційного і багатофакторного аналізу характеристик О3 надали підстав для перевірки опитувальника О3 на надійність. Зокрема, показники О3 було перевірено допомогою Tests of Normality (Табл.9).

Результати Tests of Normality для показників О3 виявились високими, що свідчить про виразність діагностованих показників.

Дані головних психометричних характеристик опитувальника О3 вміщено у Табл. 10.

За усіма шкалами О3 показник $\alpha$ Кронбаха максимально відповідає еталонному значенню для даної вибірки. Встановлені ретестові значення коефіцієнта кореляції Спірмена
$€$ достатньо високими, що засвідчує високу внутрішню узгодженість шкал О3.

Порівняльний аналіз за шкалами О3 вказав на коливання t-критерію Ст'юдента (за $\mathrm{p}<0,05)$ у межах від $-0,15$ до 0,68 , що свідчить про відсутність відмінностей на статистично значущому рівні між двома психодіагностичними замірами та достатню трасситуативну стійкість даних опитувальника.

За допомогою дискримінантного аналізу було встановлено, що показник Wilk's $L a m b d a$ для показників опитувальника О3 становить $>0,43$, що свідчить про високу достовірність виокремлення показників ОЗ. Дискримінувальні функції у моделі особистісної здійсненності мають показники іiі внутрішньої і зовнішньої форми особистісної здійсненності. 
Такі дані підкреслюють доцільність структурної характеристики особистісної здійсненності за показниками двох їі форм.

Класифікаційна матриця рівнів О3 мані результати ілюструють принципову незавершеність особистісного самоздійснення як процесу, оскільки типовим є переважання в особистісній здійсненності іiі певної форми -

Таблиияя 11.

\section{Класифікаційна матриця рівнів О3}

\begin{tabular}{|c|c|c|c|c|}
\hline & Percent - Correct & G_1:1 - $\mathrm{p}=, 01476$ & $\mathrm{G} \_2: 2-\mathrm{p}=, 69742$ & $\mathrm{G} \_3: 3-\mathrm{p}=, 28782$ \\
\hline $\mathrm{G} \_1: 1$ & 100,0000 & 8 & 0 & 0 \\
\hline G_2:2 & 97,0900 & 1 & 367 & 10 \\
\hline G_3:3 & 100,0000 & 0 & 0 & 156 \\
\hline Total & 97,9705 & 9 & 367 & 166 \\
\hline
\end{tabular}

вміщена у Табл. 11.

Результати дискримінантного аналізу показали високу достовірність виокремлення рівнів О3, зокрема загальна коректність виокремлення рівнів О3 становить майже 98\% . Відтак ми вирішили за доцільне з'ясувати ймовірність наявності типів структури О3 за допомогою кластерного аналізу методом k-

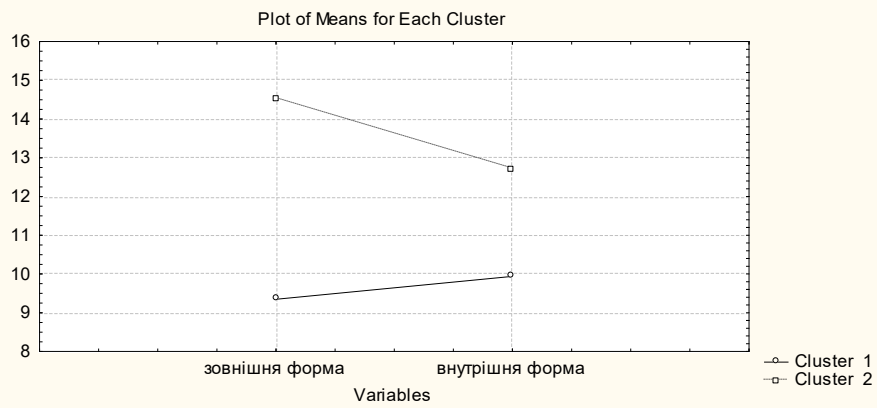

Умовні позначення: cluster 1 - перший тип особистісної здійсненності, cluster 2 - другий тип особистісної здійсненності.

Рис.4. Типи особистісної здійсненності за показниками їі зовнішньої і внутрішньої форми

середніх (Рис.4).

Результати кластерного аналізу показали, що для характеристики особистісної здійсненності співвідношення іiі внутрішньої і зовнішньої форми є визначальним. Також отри- зовнішньої або внутрішньої, що зумовлюватиме подальші зміни особистості. Відтак, можемо стверджувати, що стан особистісної здійсненності є нерівноважним, нестійким.

У зв'язку з інтерпретацією особистісної здійсненності як нестійкого стану ми встановили за допомогою класифікаційного аналізу (метод Predictor Variable Importance Rankings) рангову значущість кожного показника для загального рівня О3 (Рис.5).

Результати класифікаційного аналізу дають змогу прокоментувати, що показник внутрішньої форми О3 є для особистісної

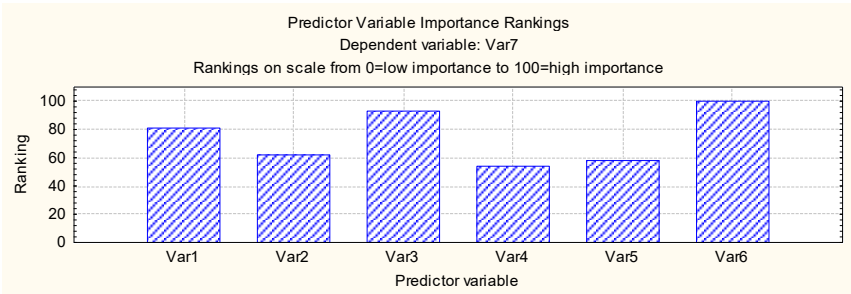

Умовні позначення: Var 1 - чітко поставлені изілі, Var 2 - прийняття Іншого, Var 3 - зовнішня форма особистісної здійсненності, Var 4 - продуктивне усамітнення, Var 5 - відповідальність за власний вибір, Var $6-$ внутрішня форма особистісної здійсненності; *ранг предиктора: 0=найменш значущий; 100=найбільш значущ⿻ий

Рис.5. Результати класифікаційного аналізу предикmopis 
здійсненності предиктором на 100 пунктів, а зовнішньої - на 93. Різниця є незначною, але
Найбільшими $\epsilon$ абсолютні величини коефіцієнтів кореляції між показниками О3 і

\section{Кореляційні зв'язки ОЗ і психологічної ресурсності* $(\mathbf{N}=\mathbf{5 0 7})$}

\begin{tabular}{|c|c|c|c|c|c|c|c|c|c|c|c|c|c|c|c|}
\hline \multirow[b]{2}{*}{ Показники О3 } & \multicolumn{15}{|c|}{ Психологічні ресурси особистості } \\
\hline & $\begin{array}{c}\text { Впев- } \\
\text { неність } \\
\text { у собі }\end{array}$ & $\begin{array}{c}\text { Добро- } \\
\text { та до } \\
\text { людей }\end{array}$ & $\begin{array}{l}\text { Допо- } \\
\text { мога } \\
\text { іншим }\end{array}$ & $\begin{array}{l}\text { Ус- } \\
\text { пix }\end{array}$ & $\begin{array}{l}\text { Лю- } \\
\text { бов }\end{array}$ & $\begin{array}{c}\text { Тво } \\
\text { рчіс } \\
\text { ть }\end{array}$ & $\begin{array}{l}\text { Вi- } \\
\text { ра у } \\
\text { до- } \\
6 \text { ро }\end{array}$ & $\begin{array}{c}\text { Праг- } \\
\text { нення } \\
\text { мудро- } \\
\text { сті }\end{array}$ & $\begin{array}{l}\text { Робо- } \\
\text { та над } \\
\text { собою }\end{array}$ & $\begin{array}{l}\text { Само- } \\
\text { реаліза } \\
\text { ція у } \\
\text { профе-- } \\
\text { сії }\end{array}$ & $\begin{array}{l}\text { Відпо- } \\
\text { відаль } \\
\text { ність }\end{array}$ & $\begin{array}{c}\text { Знання } \\
\text { влас- } \\
\text { них } \\
\text { ресур- } \\
\text { сів }\end{array}$ & $\begin{array}{c}\text { Уміння } \\
\text { оновлю- } \\
\text { вати } \\
\text { власні } \\
\text { ресурси }\end{array}$ & $\begin{array}{l}\text { Уміння } \\
\text { вміщува- } \\
\text { ти власні } \\
\text { ресурси }\end{array}$ & $\begin{array}{c}\text { Загальний } \\
\text { рівень } \\
\text { психологі- } \\
\text { чної ресур- } \\
\text { сності }\end{array}$ \\
\hline 1.Чітко поставлені цілі & 0,56 & 0,15 & 0,40 & 0,43 & 0,34 & 0,63 & 0,22 & 0,34 & 0,35 & 0,40 & 0,21 & 0,50 & 0,53 & 0,64 & 0,65 \\
\hline 2.Прийняття Іншого & 0,44 & 0,33 & 0,44 & 0,39 & 0,38 & 0,59 & 0,27 & 0,42 & 0,41 & 0,36 & 0,25 & 0,50 & 0,56 & 0,58 & 0,67 \\
\hline 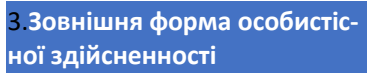 & 0,54 & 0,24 & 0,44 & 0,44 & 0,38 & 0,65 & 0,25 & 0,40 & 0,40 & 0,41 & 0,24 & 0,53 & 0,57 & 0,65 & 0,70 \\
\hline 4.Продуктивне усамітнення & 0,36 & 0,17 & 0,23 & 0,19 & 0,17 & 0,32 & 0,23 & 0,32 & 0,37 & 0,25 & 0,16 & 0,45 & 0,49 & 0,47 & 0,48 \\
\hline $\begin{array}{l}\text { 5. Відповідальність за влас- } \\
\text { ний вибір }\end{array}$ & 0,62 & 0,26 & 0,23 & 0,18 & 0,14 & 0,37 & 0,10 & 0,13 & 0,26 & 0,42 & 0,17 & 0,51 & 0,54 & 0,57 & 0,53 \\
\hline $\begin{array}{l}\text { 6.Внутрішня форма особисті- } \\
\text { сної здійсненності }\end{array}$ & 0,58 & 0,26 & 0,27 & 0,22 & 0,19 & 0,41 & 0,20 & 0,27 & 0,38 & 0,40 & 0,20 & 0,57 & 0,62 & 0,62 & 0,60 \\
\hline $\begin{array}{l}\text { 7.3агальний рівень особистіс- } \\
\text { ної здійсненності }\end{array}$ & 0,64 & 0,27 & 0,42 & 0,39 & 0,34 & 0,62 & 0,27 & 0,38 & 0,43 & 0,46 & 0,26 & 0,62 & 0,68 & 0,73 & 0,75 \\
\hline
\end{tabular}

*усі корелячіійні зв 'язки є значущчими на рівні $p<, 001$

інтерпретативно значущою.

Для перевірки змістовної валідності О3 було використано такі методики: авторський опитувальник психологічної ресурсності, опитувальник ефективності самореалізації Є. Cелезньової, методика вивчення особистісної ідентичності Л. Шнейдер, опитувальник психологічного благополуччя (адаптація С. Карсканової методики К. Ріфф), опитувальник мотиваційних цінностей (адаптація I. Семків методики PVQ Ш. Шварца), тест життєстійкості (адаптація Д. А. Леонтьевим та Є. І. Рассказовою опитувальника Hardiness Survey C. Мадді).

У Табл. 12 вміщено дані абсолютної величини коефіцієнтів кореляції показників O3 і показників психологічної ресурсності. тими показниками психологічної ресурсності, що є чинниками загального рівня $\mathrm{O} 3$, зокрема впевненість у собі і знання власних ресурсів та уміння їх оновлювати і вміщувати.

Коливання абсолютної величини коефіцієнтів кореляції головних характеристик О3 3 іншими психологічними ресурсами $є$ у діапазоні 0,10 - 0,44 ( $<0,001)$, що вказує на неідентичність методик.

Для встановлення наявності відмінностей показників О3 і самореалізації емпірично було застосовано кореляційний аналіз, результати якого вміщено у Табл.13.

Результати кореляційного аналізу показників О3 і самореалізації виявили, що загальний рівень О3 на статистично значущому рівні $(\mathrm{p}<0,05)$ не пов'язаний із такими показни- 


\section{Кореляційні зв'язки О3 і ефективності самореалізації (N=32)}

\section{Таблиияя 13.}

\begin{tabular}{|c|c|c|c|c|c|c|c|c|}
\hline \multirow{2}{*}{ Показники О3 } & \multicolumn{8}{|c|}{ Показники ефективності самореалізації } \\
\hline & $\begin{array}{c}\text { Провід- } \\
\text { ні цін- } \\
\text { ності і } \\
\text { смисло- } \\
\text { життєві } \\
\text { орієн- } \\
\text { тації }\end{array}$ & $\begin{array}{l}\text { Задово- } \\
\text { леність } \\
\text { досяг- } \\
\text { нутим } \\
\text { рівнем } \\
\text { реаліза- } \\
\text { ції жит- } \\
\text { тєвих } \\
\text { планів }\end{array}$ & $\begin{array}{l}\text { Гармо- } \\
\text { нізація } \\
\text { саморе- } \\
\text { алізації } \\
\text { у різ- } \\
\text { них } \\
\text { сферах } \\
\text { життя }\end{array}$ & $\begin{array}{c}\text { Незале- } \\
\text { жність } \\
\text { (локус } \\
\text { контро- } \\
\text { лю) }\end{array}$ & $\begin{array}{c}\text { Тер- } \\
\text { пиміс } \\
\text { ть до } \\
\text { неви- } \\
\text { значе } \\
\text { ності }\end{array}$ & $\begin{array}{l}\text { Гнуч- } \\
\text { кість у } \\
\text { поста- } \\
\text { новці } \\
\text { цілей }\end{array}$ & $\begin{array}{l}\text { Особи- } \\
\text { сті ста- } \\
\text { ндарти } \\
\text { діяль- } \\
\text { ності }\end{array}$ & $\begin{array}{c}\text { Самооці- } \\
\text { нка і } \\
\text { рівень } \\
\text { домагань }\end{array}$ \\
\hline Чітко поставлені цілі & $0,66^{* * *}$ & $0,99 * * *$ & $0,74 * * *$ & 0,19 & $0,42 *$ & $0,96^{* * *}$ & 0,45 & $0,65^{* * *}$ \\
\hline Прийняття Іншого & $0,97 * * *$ & $0,54 * *$ & 0,16 & $-0,33$ & $-0,45^{* *}$ & $0,59 * * *$ & $0,56^{* * *}$ & 0,23 \\
\hline $\begin{array}{l}\text { Зовнішня форма особис- } \\
\text { тісної здійсненності }\end{array}$ & $0,90 * * *$ & $0,88^{* * *}$ & $0,53 * *$ & $-0,06$ & 0,02 & $0,89^{* * *}$ & $0,56^{* * *}$ & $0,51^{* *}$ \\
\hline $\begin{array}{l}\text { Продуктивне усамітнен- } \\
\text { ня }\end{array}$ & $-0,44 *$ & 0,11 & $0,80^{* * *}$ & $1,00^{* * *}$ & 0,27 & $-0,05$ & $0,56^{* * *}$ & $-0,38^{*}$ \\
\hline $\begin{array}{l}\text { Відповідальність за влас- } \\
\text { ний вибір }\end{array}$ & $0,86^{* * *}$ & $0,92 * * *$ & $0,59^{* * *}$ & 0,00 & 0,11 & $0,92^{* * *}$ & $0,54^{* *}$ & $0,55^{* *}$ \\
\hline $\begin{array}{l}\text { Внутрішня форма особи- } \\
\text { стісної здійсненності }\end{array}$ & $0,73^{* * *}$ & $0,89 * * *$ & 0,27 & $-0,33$ & $0,45^{* *}$ & $0,95^{* * *}$ & $-0,04$ & $0,93^{* * *}$ \\
\hline $\begin{array}{l}\text { Загальний рівень особис- } \\
\text { тісної здійсненності }\end{array}$ & $0,89^{* * *}$ & $0,93^{* * *}$ & $0,46^{* *}$ & $-0,16$ & 0,17 & $0,96^{* * *}$ & $0,37^{*}$ & $0,69^{* * *}$ \\
\hline
\end{tabular}

$* \mathrm{p}<0,05 ; * * \mathrm{p}<0,01, * * * \mathrm{p}<0,001$

ками самореалізації, як незалежність і толерантність до невизначеності. Ми інтерпретуємо це так, що особистісна здійсненність не розкривається у прагненні людини будь-що наполягати на власному погляді на певні явища, водночас свідчить про іï схильність вислуховувати і враховувати думку інших. Невиразність О3 щодо толерантності до може бути трактована, як необов'язковість для чуття людиною власної особистісної здійсненності оцінки навколишніх і відповідності іiї досягнень 3 внутрішньої роботи до таких, що визначають- ся за безумовно успішні. Це додатково характеризує обернений зв'язок продуктивного усамітнення з показниками провідних цінностей і рівня домагань. Значною мірою особистісна здійсненність пов'язана 3 такими виявами самореалізації, як задоволеність досягнути за гнучкості постановки цілей.

Для переконання у тому, що опитувальник особистісної здійсненності розповсюджується на сферу особистісного, було здійснено кореляційний аналіз показників О3 і особистісної ідентичності (Табл.14). 
Кореляційні зв'язки О3 і особистісної ідентичності (N=105)

\begin{tabular}{|l|c|}
\hline \multicolumn{1}{|c|}{ Показники О3 } & Загальний рівень особистісної ідентичності \\
\hline Чітко поставлені цілі & $0,29^{* *}$ \\
\hline Прийняття Іншого & $0,27^{* *}$ \\
\hline Зовнішня форма особистісної здійсненності & $0,29^{* *}$ \\
\hline Продуктивне усамітнення & $0,24^{*}$ \\
\hline Відповідальність за власний вибір & $0,28^{* *}$ \\
\hline Внутрішня форма особистісної здійсненності & $0,29^{* *}$ \\
\hline Загальний рівень особистісної здійсненності & $0,29^{* *}$ \\
\hline
\end{tabular}

$* * \mathrm{p}<0,05, * * \mathrm{p}<0,01$

Абсолютні величини коефіцієнтів кореляції між показниками ОЗ і особистісної ідентичності є у межах 0,27-0,29 ( $<<0,01)$, що свідчить про змістову наближеність показників та водночас їх несумірність. Найменш тісним є зв'язок продуктивного усамітнення з особистісною ідентичністю, що, на наш погляд, підк-

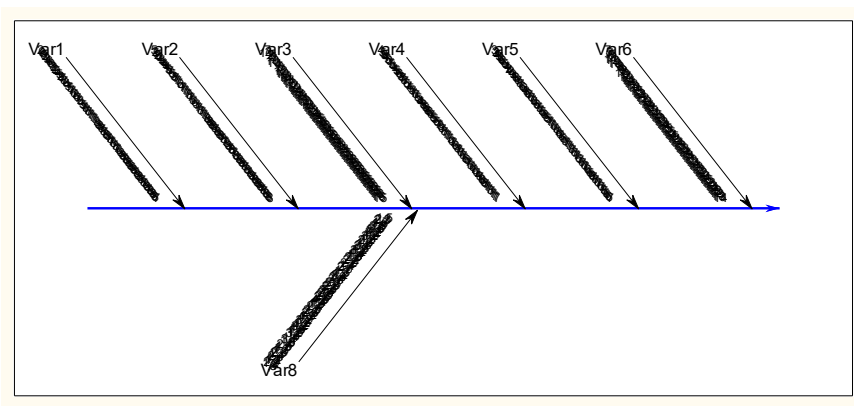

Умовні позначення: Var 1 - чітко поставлені цілі, Var 2 - прийняття Іншого, Var 3 - зовнішня форма особистісної здійсненності, Var 4 - продуктивне усамітнення, Var 5 - відповідальність за власний вибір, Var 6 внутрішня форма особистісної здійсненності

\section{Рис.6.Співвідношення показників О3 та особистісної ідентичності}

реслює слабку приналежність цього показника до сфери особистісного. 3 урахуванням даних кореляції 3 показниками екзистенціальної здійсненності (Табл.8) можливо віднести продуктивне усамітнення до сфери екзистенційного.

Способом аналізу процесів (метод Cause-And-Effect) було встановлено співвідношення показників О3 та особистісної ідентичності (рис.6).

Унаочнені на рис.6 результати аналізу співвідношення О3 і особистісної ідентичності методом Cause-And-Effect показали високу ймовірність того, що саме зовнішня форма особистісної здійсненності зумовлює ефект вияву особистісної ідентичності.

У Табл.15 вміщено абсолютні величини коефіцієнтів кореляції між показниками О3 та психологічного благополуччя (Табл.15). На основі аналізу зв'язків між О3 та психологічним благополуччям ми передбачали зроби- 
ти висновок щодо міри суб'єктивності чуття особистісної здійсненності.

Абсолютні величини коефіцієнтів кореляції між показниками О3 і психологічного благополуччя коливаються у межах 0,32-0,51 рішньої форми О3. Відтак, значний дисбаланс у показниках особистісної здійсненності на користь її зовнішньої форми може бути проінтерпретований, як вияв особистісного зростання, тобто прагнення людини бути більшою

Кореляційні зв'язки О3 і психологічного благополуччя (N=114)

\begin{tabular}{|c|c|c|c|c|c|c|}
\hline \multirow[b]{2}{*}{ Показники О3 } & \multicolumn{6}{|c|}{ Показники психологічного благополуччя } \\
\hline & $\begin{array}{c}\text { Позитивні вза- } \\
\text { ємини з інши- } \\
\text { ми }\end{array}$ & Автономія & $\begin{array}{c}\text { Управлін- } \\
\text { ня середо- } \\
\text { вищем }\end{array}$ & $\begin{array}{c}\text { Особисті- } \\
\text { сне зрос- } \\
\text { тання }\end{array}$ & $\begin{array}{l}\text { Цілі у } \\
\text { житті }\end{array}$ & $\begin{array}{c}\text { Самоприй- } \\
\text { няття }\end{array}$ \\
\hline Чітко поставлені цілі & $0,39 * * *$ & $0,38 * * *$ & $0,46^{* * *}$ & $0,43 * * *$ & $0,43 * * *$ & $0,48 * * *$ \\
\hline Прийняття Іншого & $0,41 * * *$ & $0,37 * * *$ & $0,50 * * *$ & $0,40 * * *$ & $0,47 * * *$ & $0,51 * * *$ \\
\hline $\begin{array}{l}\text { Зовнішня форма особистісної здійсненно- } \\
\text { сті }\end{array}$ & $0,41 * * *$ & $0,39 * * *$ & $0,49 * * *$ & $0,44 * * *$ & $0,46 * * *$ & $0,51 * * *$ \\
\hline Продуктивне усамітнення & $0,34 * * *$ & 0,17 & $0,32 * * *$ & $0,22 *$ & $0,24 * *$ & $0,29 * *$ \\
\hline Відповідальність за власний вибір & $0,19^{*}$ & $0,22 *$ & 0,09 & $0,26^{*}$ & 0,16 & 0,12 \\
\hline $\begin{array}{l}\text { Внутрішня форма особистісної здійснен- } \\
\text { ності }\end{array}$ & $0,32 * * *$ & $0,23 *$ & $0,25 * *$ & $0,29 * *$ & $0,24 * *$ & $0,25 * *$ \\
\hline $\begin{array}{l}\text { Загальний рівень особистісної здійснен- } \\
\text { ності }\end{array}$ & $0,39 * * *$ & $0,33 * * *$ & $0,41 * * *$ & $0,40 * * *$ & $0,35 * * *$ & $0,41 * * *$ \\
\hline
\end{tabular}

$* p<0,05 ; * * p<0,01, * * * p<0,001$

( $<<0,001)$, що свідчить про їх значну змістову наближеність, водночас неідентичність методик. Слід звернути увагу на високу щільність зв'язків між усіма показниками психологічного благополуччя і характеристиками зовнішньої форми особистісної здійсненності. Важливо, що особистісне зростання і особистісна здійсненність віддалені одне від одної за показниками внутрішньої форми особистісної здійсненності. Найменше пов'язана із психологічним благополуччям відповідальність за власний вбір. Наявні дані, на наш погляд дають змогу зробити висновки щодо доцільності відокремлення особистісної здійсненності та особистісного зростання за показниками внут- мірою зрозумілою іншим, ніж самій собі.

У зв'язку із зробленими висновками нам видалося доцільним з'ясувати зв'язок О3 і мотиваційних цінностей (Табл.16).

Результати кореляційного аналізу показників О3 і мотиваційних цінностей показали, що головною мотиваційною цінністю пов'язаною з особистісною здійсненністю є самостійність. Самостійність характеризується, як цінність напряму відкритості до змін, передбачає незалежність людини від впливу соціуму, прагнення бути творчим, мати власні погляди, визнавати індивідуальність, як власну, так і інших. Обернені зв'язки на статистично значущому рівні $(0,05)$ між показниками О3 і цін- 
ністю гедонізму вказують на те, що задоволеність людини з високим рівнем О3 досягнутим нею рівнем життєвих цілей має не гедоні- кості, що коливаються у межах 0,33-0,41 $(\mathrm{p}<0,001)$, вказує, як на змістову наближеність показників, так і на неідентичність мето-

Кореляційні зв'язки О3 і мотиваційних цінностей $(\mathrm{N}=190)$

Таблиия 16.

\begin{tabular}{|c|c|c|c|c|c|c|c|c|c|c|}
\hline \multirow[b]{2}{*}{ Показники О3 } & \multicolumn{10}{|c|}{ Показники мотиваційних цінностей } \\
\hline & $\begin{array}{l}\text { кон- } \\
\text { фор } \\
\text { мізм }\end{array}$ & $\begin{array}{c}\text { тра- } \\
\text { диці } \\
\text { я }\end{array}$ & $\begin{array}{l}\text { доб- } \\
\text { рози } \\
\text { члив } \\
\text { ість }\end{array}$ & $\begin{array}{c}\text { уні- } \\
\text { верс } \\
\text { аліз } \\
\text { м }\end{array}$ & $\begin{array}{l}\text { самос- } \\
\text { тійність }\end{array}$ & $\begin{array}{l}\text { сти- } \\
\text { мул } \\
\text { яція }\end{array}$ & $\begin{array}{c}\text { гедо- } \\
\text { нізм }\end{array}$ & $\begin{array}{l}\text { досяг- } \\
\text { нення }\end{array}$ & $\begin{array}{l}\text { вла- } \\
\text { да }\end{array}$ & безпека \\
\hline Чітко поставлені цілі & $-0,06$ & $-0,03$ & $-0,00$ & $-0,03$ & 0,12 & 0,04 & $-0,21 * *$ & $-0,15^{*}$ & $-0,06$ & 0,07 \\
\hline Прийняття Іншого & 0,10 & 0,06 & 0,10 & 0,11 & 0,10 & 0,03 & $-0,03$ & $-0,00$ & 0,02 & $0,19 * *$ \\
\hline $\begin{array}{l}\text { Зовнішня форма особис- } \\
\text { тісної здійсненності }\end{array}$ & 0,01 & 0,01 & 0,04 & 0,03 & 0,12 & 0,04 & $-0,14 *$ & $-0,10$ & $-0,03$ & 0,13 \\
\hline Продуктивне усамітнення & 0,02 & 0,01 & $-0,02$ & 0,11 & $0,35 * * *$ & 0,01 & $-0,18^{*}$ & $-0,10$ & $-0,02$ & 0,09 \\
\hline $\begin{array}{l}\text { Відповідальність за влас- } \\
\text { ний вибір }\end{array}$ & $-0,10$ & $-0,08$ & $-0,06$ & $-0,04$ & 0,07 & $-0,07$ & $-0,02$ & $-0,15^{*}$ & $-0,01$ & $-0,16^{*}$ \\
\hline $\begin{array}{l}\text { Внутрішня форма особи- } \\
\text { стісної здійсненності }\end{array}$ & $-0,05$ & $-0,04$ & $-0,05$ & 0,03 & $0,24 * * *$ & $-0,04$ & $-0,12$ & $-0,15^{*}$ & $-0,02$ & $-0,04$ \\
\hline $\begin{array}{c}\text { Загальний рівень особис- } \\
\text { тісної здійсненності }\end{array}$ & $-0,03$ & $-0,02$ & $-0,03$ & 0,08 & $0,21 * *$ & 0,02 & $-0,18^{*}$ & $-0,13$ & $-0,01$ & 0,08 \\
\hline
\end{tabular}

$* \mathrm{p}<0,05 ; * * \mathrm{p}<0,01, * * * \mathrm{p}<0,001$

стичний характер, а радше евдемоністичний, дик. Помірні зв'язки із контролем, як показнитобто задоволення через докладання зусиль. ком життєстійкості, визначають особистісну Такі результати спонукали нас до перевірки здійсненні як готовність прийняти і зрозуміти

Кореляційні зв'язки О3 і життсстійкості (N=95)

Таблиия 17.

\begin{tabular}{|l|c|c|c|c|}
\hline \multicolumn{1}{|c|}{ Показники О3 } & \multicolumn{3}{|c|}{ Показники життєстійкості } \\
\cline { 2 - 5 } & Включеність & Контроль & $\begin{array}{c}\text { Прийняття } \\
\text { ризику }\end{array}$ & $\begin{array}{c}\text { Загальний рівень жит- } \\
\text { тєстійкості }\end{array}$ \\
\hline Чітко поставлені цілі & $0,33^{* *}$ & $0,29 * *$ & $0,34^{* * *}$ & $0,37^{* * *}$ \\
\hline Прийняття Іншого & $0,31^{* *}$ & $0,26^{*}$ & $0,32^{* *}$ & $0,34^{* * *}$ \\
\hline Зовнішня форма особистісної здійсненності & $0,34^{* * *}$ & $0,29 * *$ & $0,35^{* * *}$ & $0,38^{* * *}$ \\
\hline Продуктивне усамітнення & $0,21^{*}$ & $0,28^{* *}$ & $0,27^{* *}$ & $0,29^{* *}$ \\
\hline Відповідальність за власний вибір & $0,27^{* *}$ & $0,23^{*}$ & $0,33^{* *}$ & $0,31^{* *}$ \\
\hline Внутрішня форма особистісної здійсненності & $0,29^{* *}$ & $0,30^{* *}$ & $0,36^{* * *}$ & $0,36^{* * *}$ \\
\hline Загальний рівень особистісної здійсненності & $0,33^{* *}$ & $0,30^{* *}$ & $0,41^{* * *}$ & $0,39^{* * *}$ \\
\hline
\end{tabular}

$* \mathrm{p}<0,05 ; * * \mathrm{p}<0,01,{ }^{* * *} \mathrm{p}<0,001$

співвідношення показників О3 та життєстійкості (Табл.17).

Аналіз абсолютних величин коефіцієнтів кореляції між показниками О3 і життєстій-
Іншого чи ситуацію. Непретензійність щодо впливу на події характеризують людину через особистісну здійсненність як таку, що інтерпретує себе як співавтора певних дій чи резуль- 


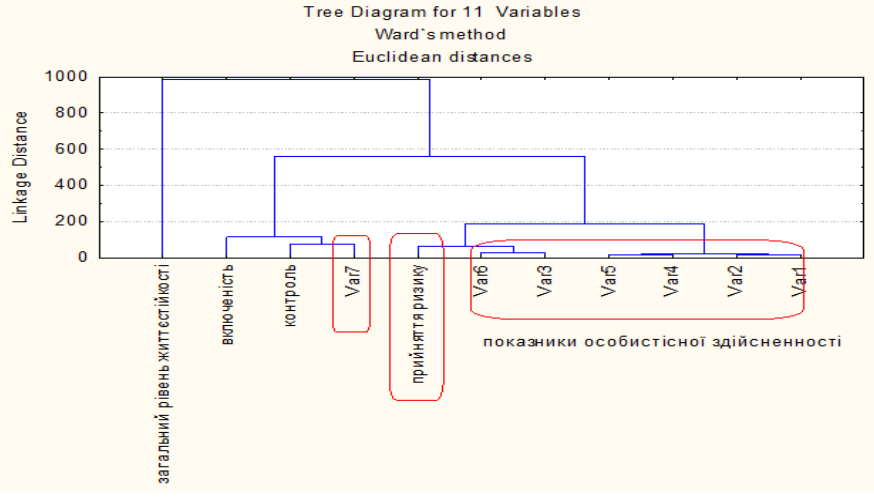

Умовні позначення: Var 1 - чітко поставлені иілі, Var 2 прийняття Іншого, Var 3 - зовнішня форма особистісной здійсненності, Var 4 - продуктивне усамітнення, Var 5 відповідальність за власний вибір, Vаг 6-внутрішня форма особистісної здійсненності, Var 7 - загальний рівень особистісної здійсненності.

\section{Рис.7. Дерево кластеризації головних харак- теристик особистісної здійсненності та показників життсстійкості}

татів. Найзначущими є зв'язки між показниками зовнішньої і внутрішньої форми ОЗ та такою компонентою життєстійкості, як прийняття ризику (характеризує переконаність людини у тому, що усе, що з нею відбувається у житті, сприяе іiі розвитку, завдяки реорганізації досвіду). Це увиразнюють і результати кластерного аналізу (Рис.7).

На Рис.7. показано, що прийняття ризику виявляється як компонента особистісної здійсненності на рівні однієї іiі форм. Водночас загальний рівень О3 постає як компонента життєстійкості. Ймовірно зафіксовані ефекти можна проінтерпретувати, як вияв особистісної трансформації, що супроводжує особистісну здійсненність і означує перехід особистості до нових життєвих завдань.
Позитивні результати апробації авторського Опитувальника особистісної здійсненності у групі з 542 особи віком 18-77 років дали підстави для презентування його завершеної версії з ключем для обчислення результатів.

\section{ОПИТУВАЛЬНИК ОСОБИСТІСНОї ЗДІЙСНЕННОСТІ}

\begin{tabular}{|c|c|}
\hline 1. & Наполегливість - це мій шлях до успіху \\
\hline 2. & Загалом, я впевнена у собі людина \\
\hline 3. & Мені не подобається відповідати за інших \\
\hline 4. & $\begin{array}{l}\text { Коли необхідно приймати рішення, я не впевнений, } \\
\text { що оберу вірний варіант }\end{array}$ \\
\hline 5. & $\begin{array}{l}\text { Я волію тримати при собі свої речі, думки та пережи- } \\
\text { вання }\end{array}$ \\
\hline 6. & Для мене важливо, щоб мої зусилля не були марними \\
\hline 7. & $\begin{array}{l}\text { Я намагаюсь уникати людей, які можуть у мене щось } \\
\text { попросити }\end{array}$ \\
\hline 8. & Не вважаю себе цілеспрямованою людиною \\
\hline 9. & $\begin{array}{l}\text { Якщо завдання відповідальне, намагаюсь його уник- } \\
\text { нути }\end{array}$ \\
\hline 10 . & Мені є кого любити \\
\hline 11. & Мені цікаві люди, які мислять самостійно \\
\hline 12. & $\begin{array}{l}\text { Я вмію надихати інших на творчі рішення або добрі } \\
\text { вчинки }\end{array}$ \\
\hline 13. & $\begin{array}{l}\text { Я вмію пропонувати свою допомогу, не принижуючи } \\
\text { людини }\end{array}$ \\
\hline 14. & Мені подобається розмірковувати, філософствувати \\
\hline 15 . & Я відчуваю життя більш повно, коли прагну цілі \\
\hline 16. & Я не бачу перспектив саморозвитку \\
\hline 17. & Я відчуваю життя більш повно, коли здатний любити \\
\hline 18. & $\begin{array}{l}\text { Час від часу мені необхідно побути наодинці, щоб } \\
\text { поміркувати над життям }\end{array}$ \\
\hline 19. & Я знаю, як себе організувати, щоб досягти мети \\
\hline 20. & $\begin{array}{l}\text { Я не знаю меж власних творчих та професійних мож- } \\
\text { ливостей }\end{array}$ \\
\hline 21. & Іншим людям важлива моя моральна підтримка \\
\hline 22. & Я не здатний робити щось, щоб почуватись у безпеці \\
\hline
\end{tabular}

Обчислення результатів: за кожну відповідність відповіді до ключа (табл.19) начислити 1 бал. Обчислити суму балів за кожною шкалою. 
Психодіагностична мета опитувальника: визначення характеристик і типу особистісної здійсненності.

Інструкція: серед наведених характеристик зазначте знаком «+» ті, що властиві вам, а «-» - ті, що не властиві. льною життєвою перспективою. Своєю чергою це зумовлює послідовність у саморозвитку i, згодом, індивідуальність життєвого шляxy.

Прийняття Іншого. Відсутність поспіху у дистанціюванні від Іншого на основі упе-

Таблиияя 18.

\section{Ключ О3}

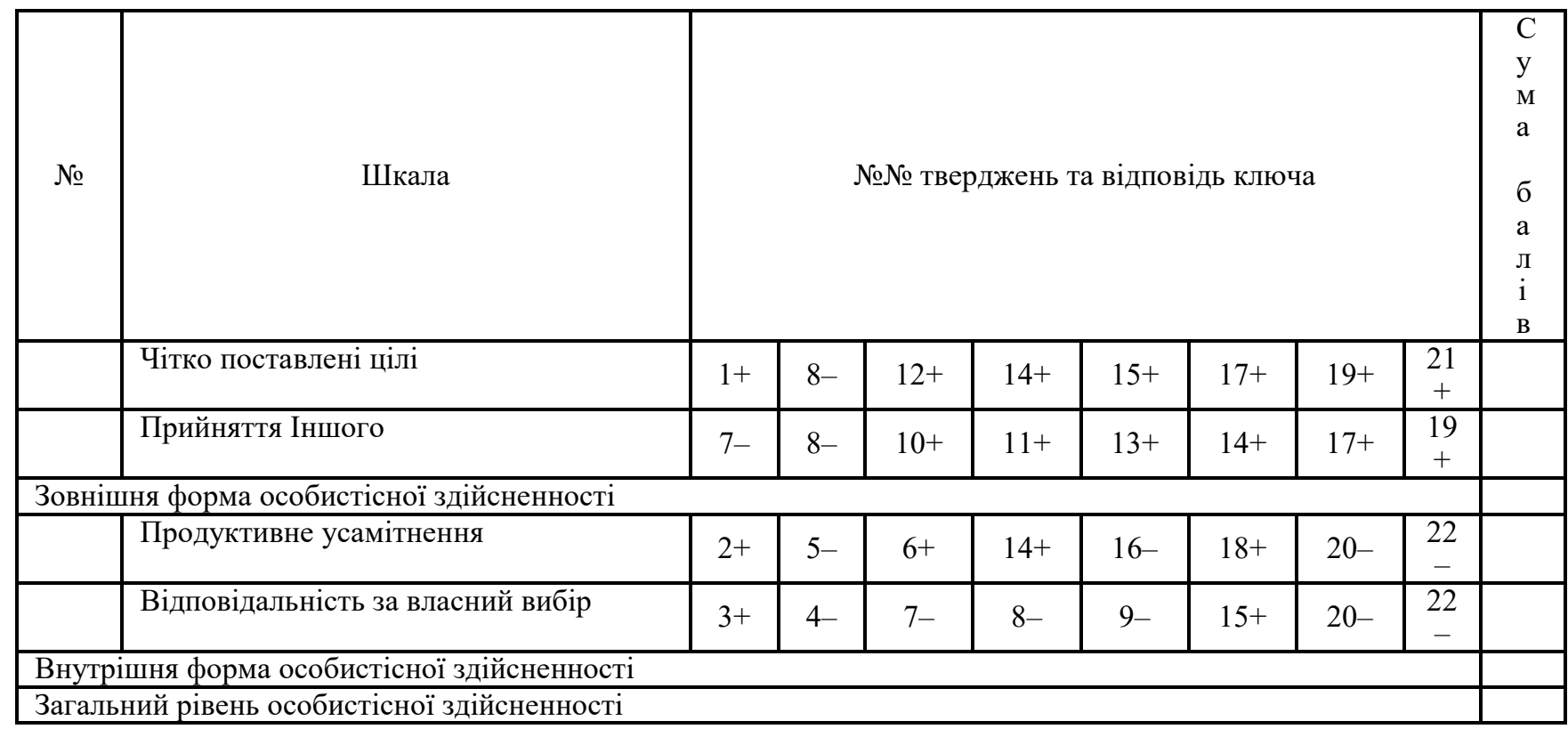

Рівні особистісної здійсненності: 0 - 12 балів - низький рівень особистісної здійсненності; 13 - 27 балів - середній рівень особистісної здійсненності; 28 - 32 балів - високий рівень особистісної здійсненності.

Інтерпретація характеристик особистісної здійсненності є такою.

Чітко поставлені цілі. Уміння самостійно і ясно формулювати власні життєві цілі різного масштабу і перспективності. Здатність відрізняти власні цілі від запропонованих чи, навіть, нав'язаних іншими. Майстерність у поєднанні і реалізації власних цілей разом із тими, що їх висунули інші. Сформульовані цілі не є кон'юнктурними, а пов'язані із зага- реджень чи недостатньої інформації. Мужність спостерігати і робити висновки під час діалогу. Сприймання труднощів у спілкуванні 3 Іншим та непорозумінь 3 ним, як власної життєвої задачі, водночас задачі не на підкорення, а на розуміння. Визнання інакшості Іншого і відмова від домінування у взаєминах. Дистанціювання від Іншого лише за наявності фактів його руйнівного впливу на власну особистість. 


\section{Зовнішня форма особистісної здійс-} ненності (бути зрозумілим для інших). Уміння чітко висловлюватися, послідовність $\mathrm{i}$ до певної міри передбачуваність у діях. Здатність пояснювати власні наміри чи дії іншим, водночас не чутися таким, що змушений виправдовуватися. Знання очікувань інших та уміння не надто їх розчаровувати. Готовність до взаємодії з іншими, що уможливлює і співпрацю.

Продуктивне усамітнення. Усамітнення саме для чогось, а не від когось. Розрізнення потреби в усамітненні і причин самотіння. Здатність організувати зовнішній простір i виокремити час для міркувань і рефлексії. Вiдсутність прагнення відволікатись, якщо є питання, що потребують роздумів і самостійного прийняття рішення. Уміння виокремлювати час для продуктивної роботи. Відмова від жалкувань щодо минулого і фантазувань щодо майбутнього, рішучість реалізовувати власні цілі на тепер. Уміння реорганізовувати власний внутрішній простір, тобто не надто захаращувати його інформацією, а також вивільнювати у ньому місце для нового досвіду чи, навіть, осяяння.

Відповідальність за власний вибір. Уміння прогнозувати наслідки власних дій та бачити власні вчинки у життєвому масштабі, а не лише у межах певної ситуації. Здатність до етичного вибору, що може не збігатися у найближчій життєвій перспективі із встановленими правилами чи вимірами раціональності.
Здатність розрізняти прагматизм і милосердність за визначення власних пріоритетів. У зв'язку із чуттям власного покликання уміння вирізняти випадок-триггер і випадок-атрактор.

Внутрішня форма особистісної здійсненності (бути зрозумілим для себе). Здатність не брехати самому собі. Уміння пояснювати будь-що самому собі, тобто інтерпретувати виходячи 3 власного досвіду водночас 3 урахуванням нової інформації. Відчуття осмисленості власних вчинків. Здатність тлумачити причини власних дій і прогнозувати наслідки власних намірів. Уміння вербалізувати власні відчуття, почуття, мотиви дій, що дасть змогу надати їх рефлексії. Переважання системної рефлексії над самозвеличенням чи самоприниженням. Уміння охарактеризувати себе влучно, 3 певним гумором, виокремлюючи сильні сторони і формулюючи очікування щодо самого себе.

\section{Загальний рівень особистісної здійс-} ненності. Чуття завершеності певного життєвого етапу, часто не пов'язаного прямо з соціальною ситуацію чи віком. Усвідомлення певних власних уявлень, очкувань, як ілюзорних. Водночас відсутність жалю за втраченими ілюзіями. Певна систематизація власного життєвого досвіду 3 акцентуванням досягнень i втрачених можливостей. Ревізія невикористаних шансів і виокремлення з них тих, що визнаються за актуальні. Можливість охарактеризувати себе, як людину, яка здатна самостійно вибрати, які можливості їх реалізувати. 
Різниця між сумою балів зовнішньої і внутрішньої форми особистісної здійсненності у 6 і більше балів інтерпретується, як дисгармонійність особистісного самоздійснення. Зокрема, переважання зовнішньої форми особистісної здійсненності свідчить про прагнення людини бути більшою мірою зрозумілою іншим, ніж собі, що перетворює іiі особистісне самоздійснення на особистісне зростання. Домінування внутрішньої форми особистісної здійсненності над зовнішньою (що встановлено у $12 \%$ досліджуваних) може бути ознакою «внутрішньої еміграції», що є наслідком соціального відчуження.

Висновки та перспективи подальших досліджень. Результати проведеного дослідження щодо особистісної здійсненності дали змогу охарактеризувати іï як ресурсний стан, що уможливлює втілення людиною розв'язання власної життєвої задачі у вчинку. Емпірично виведено, що головними характеристиками особистісної здійсненності є чітко поставлені цілі, прийняття Іншого, продуктивне усамітнення, відповідальність за власний вибір. Доведено доцільність виокремлення зовнішньої і внутрішньої форми особистісної здійсненності, які відповідно можна інтерпретувати, як здатність людини бути зрозумілою для інших i себе. Обгрунтовано, що особистісна здійсненність $€$ нерівноважним, нестійким станом, водночас значна відмінність у рівнях їі внутрішньої і зовнішньої форми може бути проінтерпретована, як дисгармонійність особистісно- го самоздійснення з ухилом в особистісне зростання чи соціальне відчуження. Підставами для таких висновків слугують результати теоретичного аналізу особистісного самоздійснення, а також емпіричні результати розробки авторського опитувальника особистісної здійсненності.

Наявність опитувальника особистісної здійсненності уможливлює емпіричні дослідження щодо пропорційності особистісної i професійної здійсненності людини у контексті iї життєвого шляху, дає змогу з'ясувати причини відчуття особистісної зреалізованості, спрогнозувати напрями і зміст саморозвитку. Вважаємо, що у найближчій перспективі через характеристики особистісної здійсненності доцільно охарактеризувати проблему особистісних деформацій.

\section{Перелік використаних джерел:}

1. Знаков В. В. Психология понимания: Проблемы и перспективы / В. Знаков. - М. : Изд-во «Институт психологии РАН», 2005. - 448c.

2. Кокун О. М. Життєве та професійне самоздійснення як предмет дослідження сучасної психології / О. Кокун // Практична психологія та соціальна робота. 2013. - №9. - C.1-5.

3. Кокун $\quad$ O. $\quad$ M. Опитувальник професійного самоздійснення / О. М. Кокун // Практична психологія та соціальна робота. - 2014. - №7. - С.35-39.

4. Корнаракис И. Фантастический христианин в сравнении со святоотеческим человеком [пер. с греч. архимандрита Симеона (Гагатика)]. - Ахтырский СвятоТроицкий монастырь, 2016. - 160с. 
5. Кривцова С. В. Шкала экзистенции (Existenzskala) A. Лэнгле и К. Орглер / С. Кривцова, А. Лэнгле, К. Орглер // Экзистенциальный анализ. Бюллетень - 2009. №1. - Москва. - С.141-170 [Елекронний ресурс]. - Режим доступу : < http://www.längle.info/downloads/ESK\% 20Krivtsova2009.pdf $>$.

6. Логинова И. О. Жизненное самоосуществление человека как проявление самоорганизации психологической системы / Ирина Олеговна Логинова. -2010. - №336. - С.169-173 [Елекронний ресурс]. Режим доступу : <http://cyberleninka.ru/article/n/y>.

7. Максименко С. Д. Поняття особистості у психології / С. Максименко // Психологія і особистість. - 2016. №1 (9). - C.11-17.

8. Мэй $P$. Искусство психологического консультирования. Как давать и обретать душевное здоровье [пер. с англ.] / Р. Мэй. - М. : Институт общегуманитарных Исследований, Апрель Пресс, 2019. - 224 c.

9. Низовских Н. А. Человек как автор самого себя: психосемантическое исследование личностного развития : монография. - М.-Берлин: Директ-Медиа, 2014. $-405 \mathrm{c}$.

10. Селезнева E. В. Грани самоосуществления: от самоотношения к самореализации : монография / Е. В. Селезнева. - М.-Берлин: Директ-Медиа, 2015. - 404 с.

11. Чепелєва H. B. Розуміння та інтерпретація особистого досвіду у контексті психологічної герменевтики [Електронний ресурс] / Н. В. Чепелєва // Наукові записки [Національного університету «Острозька академія»]. Сер. : Психологія і педагогіка [Електронний ресурс]. - 2009. - Вип. 12. - С. 8-21. Режим доступу: http://nbuv.gov.ua/j-pdf/ Nznuoapp_2009_12_4.pdf. - Мова укр.

12. Шmena O. С. Опитувальник психологічної ресурсності особистості: результати розробки й апробації авторської методики / О. С. Штепа // Проблеми сучасної психології: зб. наук. праць Кам'янець-Подільського національного університету імені Івана Огієнка, Інституту психології імені Г.С. Костюка НАПН України / за наук. ред. С. Д. Максименка, Л. А. Онуфрієвої. Вип. 39. Кам'янець-Подільський: Аксіома, 2018. - С.380-399.

13. Umena $O$. C. Теоретичний аналіз феномену особистісного самоздійснення // Актуальні проблеми психології інновацій: теорія та практика : Матеріали Всеукраїнської науково-практичної конференції (15 вересня 2017p.). - Одеса : ВМВ, 2017. - С.22-25.

14. Шmеna O. C. Тренди ресурсного дискурсу особистісного самоздійснення. Науковий вісник Миколаївського національного університету імені В. О. Сухомлинського. Психологічні науки: зб. наук. праць / за ред. Ірини Савенкової. - №2 (18). - 2017. Миколаїв: МНУ імені . О. Сухомлинського, 2017. C. 210-216.

15. Шумский $\quad$ B. $\quad$ Б. Онтологическое и персоналистическое направления в экзистенциальной психологии: сравнительный анализ / В. Шумский // Экзистенциальный анализ. - 2009. - №1. - С.181-198.

16. Як будувати власне майбутнє: життєві завдання особистості : наук. моногр. / за наук. ред. т. М. Титаренко; Національна академія педагогічних наук України, Інститут соціальної та політичної психології. - Кіровоград : Імекс-ЛТД, 2012. - 512c.

\section{References (Transsliteration):}

1.Znakov $V . \quad V$. Psihologiya ponimaniya: Problemy i perspektivy / V. Znakov. - M. : Izd-vo «Institut psihologii RAN», 2005. - 448s.

2. Kokun O. M. Zhy'ttyeve ta profesijne samozdijsnennya yak predmet doslidzhennya suchasnoyi psy`xologiyi / O. Kokun // Prakty`chna psy`xologiya ta social’na robota. 2013. - \#9. - S.1-5.

3. Kokun O. M. Opy`tuval'ny'k profesijnogo samozdijsnennya / O. M. Kokun // Prakty`chna psy`xologiya ta social’na robota. - 2014. - \#7. - S.35-39.

4. Kornarakis I. Fantasticheskij hristianin v sravnenii so svyatootecheskim chelovekom [per. s grech. arhimandrita Simeona (Gagatika)]. - Ahtyrskij Svyato-Troickij monastyr', 2016. - 160s. 
5. Krivcova $S$. $V$. SHkala ehkzistencii (Existenzskala) A. Lehngle i K. Orgler / S. Krivcova, A. Lehngle, K. Orgler // EHkzistencial'nyj analiz. Byulleten' - 2009. - №1. Moskva. - S.141-170 [Elekronnij resurs]. - Rezhim dostupu : $\quad<$ http://www.längle.info/downloads/ESK\% 20Krivtsova2009.pdf $>$.

6. Loginova I. O. ZHiznennoe samoosushchestvlenie cheloveka kak proyavlenie samoorganizacii psihologicheskoj sistemy / Irina Olegovna Loginova. 2010. - №336. - S.169-173 [Elekronnij resurs]. - Rezhim dostupu : $<$ http://cyberleninka.ru/article/n/y>.

7. Maksy`menko S. $\quad$ D. Ponyattya osoby`stosti u psy`xologiyi / S. Maksy`menko // Psy`xologiya i osoby`stist'. - 2016. - \#1(9). - S.11-17.

8. Mehj R. Iskusstvo psihologicheskogo konsul'tirovaniya. Kak davat' i obretat' dushevnoe zdorov'e [per. s angl.] / R. Mehj. - M. : Institut obshchegumanitarnyh Issledovanij, Aprel' Press, 2019. - 224s.

9. Nizovskih N. A. CHelovek kak avtor samogo sebya: psihosemanticheskoe issledovanie lichnostnogo razvitiya : monografiya. - M.-Berlin: Direkt-Media, 2014. - 405s.

10. Selezneva E. $\quad V$. Grani samoosushchestvleniya: ot samootnosheniya $\mathrm{k}$ samorealizacii : monografiya / E. V. Selezneva. - M.-Berlin: Direkt-Media, 2015. - 404s.

11. Chepelyeva $N . \quad V$. Rozuminnya ta interpretaciya osoby`stogo dosvidu u konteksti psy`xologichnoyi germenevty`ky` [Elektronny`j resurs] / N. V. Chepelyeva // Naukovi zapy`sky` [Nacional'nogo universy`tetu «Ostroz`ka akademiya»]. Ser. : Psy`xologiya i pedagogika [Elektronny’j resurs]. - 2009. - Vy’p. 12. - S. 8-21. Rezhy'm dostupu: http://nbuv.gov.ua/j-pdf/ Nznuoapp_2009_12_4.pdf.

12. Shtepa O. S. Opy`tuval`ny`k psy`xologichnoyi resursnosti osoby`stosti: rezul 'taty` rozrobky` $\mathrm{j}$ aprobaciyi avtors`koyi metody`ky' / O. S. Shtepa // Problemy` suchasnoyi psy`xologiyi: zb. nauk. pracz' Kam'yanecz`Podil's`kogo nacional’nogo universy`tetu imeni Ivana Ogiyenka, Insty`tutu psy’xologiyi imeni G.S. Kostyuka NAPN Ukrayiny` / za nauk. red. S. D. Maksy`menka, L. A.
Onufriyevoyi. Vy`p. 39. Kam'yanecz'-Podil`s`ky`j: Aksioma, 2018. - S.380-399.

13. Shtepa O. S. Teorety`chny`j analiz fenomenu osoby`stisnogo samozdijsnennya // Aktual'ni problemy' psy`xologiyi innovacij: teoriya ta prakty'ka : Materialy` Vseukrayins 'koyi naukovo-prakty'chnoyi konferenciyi (15 veresnya 2017r.). - Odesa : VMV, 2017. - S.22-25.

14. Shtepa $\quad$ O. S. Trendy` resursnogo dy`skursu osoby`stisnogo samozdijsnennya. Naukovy`j visny`k My`kolayivs`kogo nacional’nogo universy`tetu imeni V. O. Suxomly`ns`kogo. Psy`xologichni nauky`: zb. nauk. pracz` / za red. Iry`ny` Savenkovoyi. - \#2 (18). - 2017. My`kolayiv: MNU imeni . O. Suxomly`ns`kogo, 2017. S.210-216.

15. Shumskij V. B. Ontologicheskoe i personalisticheskoe napravleniya $\mathrm{v}$ ehkzistencial'noj psihologii: sravnitel'nyj analiz / V. SHumskij // Ekzistencial'nyj analiz. - 2009. №1. - S.181-198.

16. Yak buduvaty vlasne majbutnye: zhy`ttyevi zavdannya osoby`stosti : nauk. monogr. / za nauk. red. t. M. Ty’tarenko; Nacional'na akademiya pedagogichny’x nauk Ukrayiny`, Insty`tut social'noyi ta polity`chnoyi psy`xologiyi. - Kirovograd : Imeks-LTD, 2012. - 512s.

\section{Shtepa Olena}

Ph. D. in Psychological Science, Assistant Professor, Assistant Professor of the Department of Psychology, Ivan Franko National University of Lviv, Lviv (Ukraine)

THE QUESTIONNAIRE OF A PERSONALITY'S FULFILLMENTITY: THE THEORETICAL GROUNDS FOR CREATION AND THE RESULTS OF APPROBATION

\section{ABSTRACT}

The applied problems of personal selffulfillment are characterized and the expediency of the term "personality fulfillment" is substantiated. It is theoretically analyzed, that the characterization of self-realization in concepts (pre) cer- 
tainty led to the identification of this concept with self-realization and its inexpressiveness among the psychological characteristics of the individual.

It is substantiated that personality selffulfillment should be characterized as one of the modes of vital self-realization, which, in relation to professional self-realization, determines the uniqueness of a person's life path. It is stressed that self-realization is revealed precisely in the existential perspective.

The features of the interpretation of personality self-fulfillment in the personalistic and ontological directions of the existential psychology of personality are analyzed. It is theoretically justified that the extreme points of the continuum of personal self-realization are "authenticity - fantasticity". It is substantiated that psychological resources can be units "making possible" the discreteness of personality self-fulfillment. Personality's fulfillmentity is characterized as a resource state, which makes it possible for a person to fulfill his own life task in an doing.

In the empirical determination of the conservative structure of psychological resources, as well as in the development and approbation of a personality questionnaire of the personality's fulfillmentity, 542 people aged 18-77 years were involved. The results of regression analysis revealed that, on the whole, $62 \%$ of psychological resources are components of personality's fulfillmentity. The main psychological resources, that characterize both the process and the structure of personality self-fulfillment, are the knowledge of their resources and the ability to invest and update them (is the pointer of psychological resourceful as the ability to operate with their own resources), as well as self-confidence, kindness to people, the pursuit of wisdom, creativity, work on yourself.

The results of development and approbation of the author's questionnaire of personality's fulfillmentity are given. On the basis of the results of exploratory factor analysis, a two-factor stable structure of personal fulfillment is defined, which as a whole accounts for $88 \%$ of the variance. Factor $1(70 \%)$ includes such characteristics of personality's fulfillmentity, as clearly defined goals and acceptance of the Other, as well as a general indicator of the external form of personality's fulfillmentity, which characterizes a person's ability to be understandable to others. Factor 2 (18\%) includes such characteristics of personality's fulfillmentity as productive solitude and responsibility for one's own choice, as well as an indicator of the internal form of personality's fulfillmentity that characterizes a person's ability to be understandable for himself.

The characterization of content of personal fulfillment was refined through a description of its correlation with indicators of existential fulfillmentity, self-realization, personal identity, psychological well-being, motivational values, hardiness.

Key words: personality, personality fulfillment, personality's fulfillmentity, personality's 
questionnaire.

\section{Штепа Елена Станиславовна}

Кандидат психологических наук, доцент, дочент кафедры психологии, Львовский национальный университет имени Ивана Франко, г. Львов (Украина)

\section{ОПРОСНИК ЛИЧНОСТНОЙ ИСПОЛНЕННОСТИ: ТЕОРЕТИЧЕСКИЕ ОСНОВАНИЯ ДЛЯ РАЗРАБОТКИ И РЕЗУЛЬТАТЫ АПРОБАЦИИ}

Аннотация. Охарактеризованы прикладные проблемы личностного самоосуществления и обоснована целесообразность термина «личностная исполненность». Теоретически проанализировано, что характеристика самоосуществления в концептах (пред) определенности привело к отождествлению этого понятия з самореализацией и его невыразительность среди психологических характеристик личности. Обосновано, что личностное самоосуществление следует охарактеризовать, как один из модусов жизненного самоосуществления, который в соотношении с профессиональным самоосуществлением обуславливает уникальность жизненного пути личности. Акцентировано на том, что самоосуществление раскрывается именно в экзистенциальном ракурсе. Проанализированы особенности истолкования личностного самоосуществления в персоналистическом и онтологическом направлениях экзистенциальной психологии личности. Теоретически обосновано, что крайними точками континуума личностного самоосуществления являются «подлинность - фантастичность». Обосновано, что психологические ресурсы могут быть единицами «увозможнивания» дискретности личностного самоосуществления. Личностную исполненность охарактеризовано как ресурсное состояние, которое делает возможным воплощение человеком решения собственной жизненной задачи в поступке.

В эмпирическом установлении консервативной структуры психологических ресурсов, а также в разработке и апробации опросника личностной исполненности были задействованы 542 человека в возрасте 18-77 лет. Результаты регрессионного анализа выявили, что, в целом, 62\% психологических ресурсов являются компонентами личностной исполненности. Основными психологическими ресурсами которые характеризуют, как процесс, так и структуру личностной исполненности являются знание своих ресурсов и умение их вкладывать и обновлять (собственно, показатели психологической ресурсности как умения оперировать собственными ресурсами), а также уверенность в себе, доброта к людям, стремление к мудрости, творчество, работа над собой.

Приведены результаты разработки и апробации авторского опросника личностной исполненности. На основе результатов экспораторного факторного анализа определена двухфакторная устойчивая структура личностной исполненности, которая в целом объясняет $88 \%$ дисперсии. В фактор 1 (70\%) вошли 
такие характеристики личностной исполненности, как четко поставленные цели и принятие Другого, а также общий показатель внешней формы личностной осуществленности, который характеризует способность человека быть понятным для других. В фактор 2 (18\%) вошли такие характеристики личностной исполненности, как продуктивное уединение и ответственность за собственный выбор, а также показатель внутренней формы личностной исполненности, который характеризует способность человека быть понятным для себя.

Содержательная характеристика личностной исполненности уточнена через описание ее корреляционных связей с показателями экзистенциальной исполненности, самореализации, личностной идентичности, психологического благополучия, мотивационных ценностей, жизнестойкости.

Ключевые слова: личность, личностное самоосуществление, личностная исполненность, личностный опросник. 